\title{
Busting the Boom-Bust Pattern of Development in the Brazilian Amazon
}

\begin{abstract}
Global ecosystem services are clearly threatened by deforestation associated with the human occupation and economic development of the Brazilian Amazon. However, the prognosis for the socioeconomic wellbeing of inhabitants remains unclear. In an empirical regularity that has been termed the "boom-bust" pattern or the "resource curse," the exploitation of natural resources is associated with short-run gains in welfare that dissipate over time. This "coupling hypothesis" asserts that deforestation and development are correlated such that deforestation leads to only short term advances in economic welfare that are not sustained once natural forests (along with their mature timber and soil inputs) are exhausted. In contrast, the "decoupling hypothesis" asserts that deforestation and development need not be correlated over time. In this context, growth that is initially based on deforestation may be sustained and translated into prolonged welfare gains, even once the forest is exhausted. Using census and deforestation data from 1991, 2000 and 2010 for municipalities (i.e. counties) in the Amazon region we confirm that this boom-bust pattern appears in cross-sectional data. However, using panel data we show that socioeconomic welfare has become decoupled from environmental factors and is converging to rising national averages. Our findings contradict the conventional wisdom that the exploitation of tropical forests is required to promote Amazonian development.
\end{abstract}

Key words: boom-bust; convergence; deforestation; Amazon; Brazil; Solow growth model; catch-up effect

\section{Acknowledgements}

This research was funded by the National Science Foundation, under grant SES-0752936 


\section{INTRODUCTION}

The colonization of the Brazilian Amazon has been a contentious topic of debate for over four decades with development objectives pitted against conservation concerns (Goodland and Irwin 1975). This is not surprising given that the region contains unmatched levels of biodiversity (Godoy et al. 2009; Gibson et al. 2011) in vast terrestrial and aquatic ecosystems (Hess et al. 2003) supporting both the largest river system (by discharge) on earth and an enormous stock of carbon in the forest biomass (Nogueira et al. 2008; Brando et al. 2008). Continued land-use change has the potential to impact the global hydrological cycle via biogeophysical processes that affect the energy balance of Earth's surface (Feddema et al. 2005) and increase ecosystem vulnerability via anthropogenic (Uriarte et al. 2012; Brondizio and Moran 2008) and non-anthropogenic feedback effects (Davidson et al. 2012).

The global, national, and local ecosystem services provided by the Amazon biome are clearly threatened by deforestation associated with human occupation and development (Nobre 2014; Laurance et al. 1999; Nepstad et al. 1999). However, the prognosis for the long-term economic and social wellbeing of the inhabitants of the region remains unclear (Ioris 2015; Guedes et al. 2014; Guedes et al. 2012). One prediction is that growth will ultimately slow in the Amazon because economic booms associated with exploiting old-growth forest are short-lived and dissipate once the forest is depleted (e.g. Rodrigues et al. 2009). Such a "boom-bust" pattern could be caused by reliance on low cost natural resource inputs that eventually increase in price as their relative scarcity increases. For example, if tropical soils are inherently poor, fertile agricultural land will only be available as an input to production for a short period following 
deforestation (Lu, Moran and Mausel 2002). Alternatively, the process of deforestation may directly affect the growth trajectory. For example, the resource curse literature suggests that high rents associated with deforestation may discourage investment in other sectors and increase corruption (Barbier 2005). Both the "rising input costs" and the "political economy" explanations suggest that growth of income and welfare will initially rise, but will ultimately decline as deforestation progresses, potentially becoming negative.

However, it is also possible that growth rates achieved during periods of rapid deforestation will be sustained even after the forest resource is exhausted. In theory, if resource rents are reinvested in physical or human capital, and if there are sufficient possibilities for substitution between natural resources and other inputs, growth will not necessarily slow as resources become scarce (Solow 1974; Stiglitz 1979). In this case, growth initially based on deforestation will ultimately become decoupled from natural resources, and thus patterns of growth and development in the Brazilian Amazon could follow those of other regions in Brazil. Specifically, neoclassical growth theory predicts that long-term growth rates will depend on technical progress, and that countries and regions will converge with one another, conditional on their production technologies and institutions (Solow 1956).

Understanding the relationship between development and deforestation in the Brazilian Amazon is increasingly relevant for policy at the national and global levels. Under the 2004 National Plan to Prevent and Control Deforestation in the Brazilian Amazon (PPCDAm), the Brazilian government significantly expanded the protected area network; made progress towards clarifying land tenure; and employed the world's largest and most advanced real-time deforestation monitoring system (DETER - Detection of Deforestation in Real Time) to strengthen enforcement of existing command and control policies in the Amazon (Assunção, 
Gandour and Rocha 2012). These efforts met with significant political resistance from the agricultural and pro-development lobbies, which have sought to undermine environmental laws including the Brazilian Forest Code (May, Millikan and Gebara 2011). In Brazil, the political debate about measures to reduce deforestation often focuses on their expected negative implications for economic development.

Brazil has taken significant steps towards setting targets and developing strategies for REDD+ (Reducing Emissions from Deforestation and Degradation) under the United Nations Framework Convention on Climate Change. There are also numerous sub-national initiatives in the Brazilian Amazon ranging from state government programs to private projects to generate offset credits for the voluntary market (Sills et al. 2014; Duchelle et al. 2014; Lin et al. 2012). Persistent concerns have been raised about the potential impacts of REDD+ on local livelihoods and socioeconomic welfare (Ghazoul et al. 2010; Chhatre et al. 2012). While these impacts depend in part on the particular interventions used to achieve REDD+, they also depend on the general relationship between deforestation, growth and development.

Thus, evidence for the long-term impacts of deforestation on economic growth is needed to better inform national and global policy debates on reducing tropical deforestation. The relationship between protecting the valuable ecosystem services provided by intact tropical forest and improving the wellbeing of households in developing countries cannot be fully understood by studying incomes or standards of living in a single time period. In particular, rapid growth may be observed while deforestation is occurring, but it may or may not be sustained over time. Empirical regularities observed in cross-sectional data have led observers to expect one of two patterns to result from the dynamics of deforestation and development. First, the "coupling hypothesis" asserts that deforestation and development are correlated such that 
deforestation leads to only short term advances in economic welfare that are not sustained once natural forests (along with their mature timber and soil inputs) are exhausted and no more deforestation is possible. Although the temporal relationship between deforestation and economic growth would differ, this hypothesis is consistent with both the "boom-bust" and the "resource curse." In either case, the trade-offs between protection of ecosystem services and improvements in living standards are likely to be high in the short term, but low in the long term because growth based on deforestation is not likely to be sustained. Any negative economic impacts of policies to avoid deforestation are therefore lower than the immediate benefits from deforestation would suggest.

In contrast, what we term the "decoupling hypothesis" asserts that deforestation and development need not be correlated over time. In this context, growth that is initially based on deforestation may be sustained and translated into prolonged welfare gains, even once the forest is exhausted. This could mean that deforestation-growth tradeoffs are substantial, but also suggests that it may be possible to find ways other than deforestation to generate those sustained welfare gains, since they are not tied directly to deforestation. For example, if substantial REDD+ payments or any profits from deforestation were invested in human and physical capital, the result could be more sustained growth than achieved with deforestation. If municipal economies become decoupled from the resource base as forests become scarce and/or the population becomes more urbanized, the immediate opportunity costs of limiting deforestation may dissipate over time.

We use Brazilian census and deforestation data from 1991, 2000 and 2010 for municipalities (i.e. counties) in the Amazon region to test these hypotheses and describe the trajectories of economic growth and development during periods of active deforestation. Our 
findings are consistent with the "decoupling hypothesis" and provide evidence of a neoclassical growth pattern of convergence (Barro 1991) for the Amazon and across all municipalities in Brazil.

\section{DEFORESTATION-GROWTH HYPOTHESES}

The use of natural resources such as tropical forests can profoundly impact the growth and development of an economy. While rapid growth is expected during the early stages of deforestation due to abundant low-cost inputs, the growth path of an economy once forests become scarce is ambiguous. Standard neoclassical models of economic growth do not directly address the role of natural resources as an input to production, or the potential implications of resource scarcity for the sustainability of growth rates over time. In these models, the growth of output per worker depends on the change in the capital stock per worker and the rate of technical progress (see Solow 1956). If diminishing returns to capital are assumed, higher levels of saving and capital investment can only raise output growth in the short run. In the long run, growth will revert to a steady state determined by the rate of technical progress. As a result, economies with similar institutional characteristics are predicted to converge over time because those with low initial levels of capital and income experience greater returns to capital investment, and therefore grow faster than those with higher initial capital and income.

To expand this model, natural resources per worker (n) can be explicitly included in the production function along with human and physical capital per worker $(\mathrm{k})$ :

$$
y=f(k, n)
$$

Within this framework, increasing use of natural resources will result in growth of output per worker $(y)$, with the nature of the relationship dependent on the functional form assumed (i.e. diminishing, constant, or increasing returns). 
Neoclassical analysis of the economics of natural resources (Solow 1974; Stiglitz 1974; Dasgupta and Heal 1974) has shown that in the case of non-renewable resources, growth rates can be sustained as natural resources become scarce provided that the elasticity of substitution between (physical and human) capital and natural resources is greater than 1. In other words, if the prices of natural resource inputs rise as they become more scarce (as in a competitive market setting), and if it is possible to substitute capital for natural resources, then substitution is expected to take place. This may be the result of substitution of inputs (for example, using manufactured fertilizer as soil fertility declines), or substitution of outputs (such as shifting from raw agricultural products to processed goods). In either case, the share of natural resources in aggregate economic output declines. This makes the impact of resource scarcity on growth selflimiting because the rise in prices of natural resources has less impact on growth as their contribution to overall production declines (Solow 1978). In contrast, if the elasticity of substitution is less than one (such that substitution of natural resources for capital does not readily occur), growth will slow as the costs of natural resource inputs rise.

In the context of deforestation, natural resource inputs include both timber from forested land and the fertile agricultural land available immediately after forest clearing. Both of these have been characterized as 'non-renewable' when old growth forests are cleared, due to the slow growth rates of natural forest and inherent limitations of tropical soils (Davidson and Martinelli 2009; Foley et al. 2007). However, the implications of the above models are similar in principle for renewable resources, suggesting that as resource availability declines, there may be substitution into capital inputs or application of capital inputs to recover the natural resources, e.g. through reforestation or improvements in soil fertility. 
This model of the relationship between natural resources and growth suggests that as forest cover in Brazilian municipalities declines, growth will slow if there is limited substitution between natural resources and other inputs to production. However, if there is good potential for substitution, a shift into production based on man-made capital and labor would be expected. This may entail changes in production technologies and associated changes in input mixes, but it could also result from shifts in the types of goods and services produced (Stiglitz, 1979) such as a transition from tropical hardwood timber and subsistence crops, to more input-intensive agricultural commodities and plantation timber to non-agricultural activities in conjunction with increased urbanization.

Thus, the two competing hypotheses (the "coupling" and "decoupling" hypotheses) reflect, in part, different underlying assumptions about the ease of substitution between natural resources and capital. If there are limited options for the substitution of natural resources (as the coupling hypothesis assumes), the growth of aggregate output will slow as natural resource scarcity increases,. On the other hand, if substitution is relatively easy, the increase in prices experienced as natural resources become scarcer does not necessarily affect growth rates. In this case, timber availability or soil fertility may still fall, but the affected sectors would adopt alternative production technologies or output combinations that are intensive in alternative inputs. Implicit in this decoupling hypothesis is the assumption that income resulting from the initial resource exploitation is re-invested in some form of capital, whether physical, human, or natural (e.g., through reforestation or soil improvements). An alternative mechanism that could also lead to "coupling" of deforestation and growth is a lower rate of saving and investment of resource rents than other sources of income, such as suggested in the literature on the "resource curse" (Barbier 2005). If the high resource rents earned from deforestation lead to increased 
corruption, underinvestment in capital, or are simply moved out of the region, deforestation is unlikely to have a sustained positive impact on growth.

In this paper, we test whether economic growth is coupled with deforestation in the Brazilian Amazon. Specifically, we test the null "coupling" hypothesis that the rate of increase in income and welfare initially rose and then fell with deforestation, as reflected in the cumulative total deforestation in a municipality at the end of each period. Such a pattern could be driven by the rising costs of natural resource inputs and/or political economy factors that hinder other sectors. In either case, the proximate cause of the bust is a lack of investment in alternative forms of capital during the boom period, whether due to low substitutability of inputs or poor institutional or financial incentives to invest. Under the alternative hypothesis of decoupling, economic growth is still predicted in the early stages of deforestation, but as more land is cleared, the relationship between forest resources and economic growth weakens. Standard neo-classical economic growth theory (Dawson and Strazicich 2010; Lei and Tam 2010; Sala-iMartin 2006; Barro and Sala-I-Martin 1991) instead predicts convergence between low income and high income municipalities, conditional on institutional and other characteristics that determine the production function. Thus, municipalities may converge to a regional average for northern Brazil, based on their similar institutional and biophysical factors, or to a national average, supported by Brazilian federal policies that help less-developed municipalities and states catch-up to the national average (Liu 2009; Abramovitz 1986).

\section{METHODS}

(a) Study Areas 
Our first scope of analysis includes the municipalities in the Amazon Biome in Brazil, defined as municipalities that had at least $70 \%$ mature forest cover ${ }^{1}$ in 1960 before the region experienced large scale settlement and migration. Following the selection criteria of Rodrigues et al. (2009), and using the nearly-cloudless (mean=0.93 per municipality) 2000 INPE classified land cover imagery (INPE 2000), we dropped all municipalities that i) were not fully inside the Legal Amazon political boundary $(n=26)$, ii) did not have at least $70 \%$ original (1960) forest cover according to INPE data $(n=217)$, or iii) had $>5 \%$ of their area covered by pixels of unknown status in 2000 due to cloud cover $(n=126)$. Applying the same criteria to the 2010 data, we increased the sample by nine municipalities $(n=9)$ due to fewer unknown pixels in the 2010 classification, for a total of 423 municipalities in 2010 (Figure 1A). Our second scope of analysis includes all 5,565 Brazilian municipalities (Figure 1B). Choosing municipalities as our unit of analysis allows us to compare results to previous literature (Rodrigues et al. 2009 and Celentano et al. 2012) and to use the rich databases on municipalities provided by Brazilian public agencies. One caveat is that this level of analysis obscures the heterogeneity in size of municipality, both in terms of land area and in terms of population.

(Figure 1 here)

\section{(b) Data}

Our analysis of the relationship between deforestation and development in the Amazon uses: 1) the municipality Human Development Index (HDI: the average of life expectancy, literacy, and standard of living indices) and the municipality Income Index (or the "standard of living" index from the HDI) derived by the United Nations Development Project (PNUD 2013) based on IBGE's (Brazilian Institute of Geography and Statistics) population census in 1991,

\footnotetext{
${ }^{1}$ We use the cut off suggested by Rodrigues et al (2009). Robustness checks using (a) a cut off of $50 \%$ as suggested by Celentano et al. (2012) and (b) including all municipalities in the Amazon (not using any cutoff) result in the same conclusions as drawn here.
} 
2000 , and 2010; 2) remote sensing data at the state level in 1991 and municipal level in 2000 and 2010, downloaded from the PRODES Project of the Brazilian Institute for Spatial Research (INPE) (INPE 2011; INPE 2007); and 3) IBGE population data (IBGE 2014); and. These three data sources were joined and summarized for the 2010 political division of 783 municipalities within the Brazilian Legal Amazon (INPE 2011; IBGE 2012), then narrowed to 423 municipalities based on the criteria explained above.

The HDI is intended to represent overall socioeconomic well-being (or welfare) by combining information on life expectancy, education, and income. ${ }^{2}$ These three components are equally weighted to create an index with values ranging from 0 to 1 , with higher values associated with higher levels of human development. The index was introduced as part of the United Nations Development Programme (UNDP) initiative to shift the focus of economic development policy from income growth to human welfare and is annually reported for most nations across the globe with values dating back to 1960 (PNUD 2013). UNDP divides nations into four categories according to this measure: very high HDI nations (with 2013 values at and above 0.8), high HDI nations (with 2013 values between 0.7 and 0.79), medium HDI countries (with 2013 values between 0.5 and 0.69) and low HDI countries (with values below 0.5). Brazil's HDI increased from 0.51 in 1980 to 0.73 in 2013, placing the nation within the high HDI countries. We use the HDI to measure socio-economic development in a municipality, and its income component to measure economic growth. Specifically, the "Income Index" is gross municipal income divided by the number of people living in the municipality, converted to dollars at purchasing power parity, with 2005 as the reference year (PNUD 2013).

Descriptive statistics for the HDI, income index and deforestation ratio (defined as

\footnotetext{
${ }^{2}$ The HDI may not be an appropriate measure of welfare among indigenous people who value traditional knowledge over formal education and who operate largely outside the market economy, making their income difficult to measure.
} 
original forest cover lost as a percent of municipal land area) for the 423 municipalities in our sample are summarized by state for 1991, 2000, and 2010 in Table 1. Here we reference the 2000-2010 as our main model and include 1991-2000 and 1991-2010 as checks because the 1991 municipal level deforestation data are extrapolated from state averages. ${ }^{3}$ The average municipality deforestation ratio increased from $12 \%$ in 1991 to almost $50 \%$ in 2010 for our Legal Amazon sample. States along what is known as the "arc of deforestation" or the northeast to southwest perimeter of the Legal Amazon had the highest average municipality deforestation ratios in 2010; for example, the 26 municipalities in Tocantins that were originally more than $70 \%$ forested had an average deforestation ratio of $83 \%$ in 2010 . Over this time period, the average HDI for municipalities in our sample doubled from an average of 0.30 in 1991 to 0.60 in 2010. In comparison, the average HDI of all municipalities in the nation increased at a slightly slower rate from 0.38 to 0.66 for this same time period, resulting in a smaller gap between the nation and the Amazon by 2010. Nonetheless, average HDI remained substantially lower in municipalities in the Legal Amazon than in the rest of the nation in all three time periods (Figure 2). The average Income Index of the Amazonian municipalities also increased from 0.48 in 1991 to 0.59 by 2010 , but remained below the national average.

(Table 1 here)

(Figure 2 here)

\section{(c) Analysis}

\footnotetext{
${ }^{3}$ Because 1991 deforestation levels are not available by municipality, we assume that the distribution of deforestation within a state in 1991 is the same as in 2000: $\operatorname{Def}(\mathrm{i}) 1991=\operatorname{Def}(\mathrm{i}) 2000-\{\operatorname{Def}(\mathrm{i}) 2000 *$ [(Def(j)2000 $\operatorname{Def(j)1991)/Def(j)2000)~]~\} ~}$
} 
We first investigate whether welfare appears coupled with deforestation among municipalities within the Amazon Biome. We graph the relationship between deforestation and changes in HDI, and test for a quadratic relationship using Ordinary Least Squares (OLS) regression ${ }^{4}$. If there is a "boom-bust" economic cycle related to deforestation, the HDI and Income Index would increase with deforestation across municipalities with low deforestation levels and decrease with deforestation across municipalities with high deforestation levels. A "boom-bust" pattern would be evidenced by a positive and significant coefficient on the deforestation ratio (Deforestation) and a negative and significant coefficient on its square $\left(\right.$ Deforestation $^{2}$ ) with a turning point within the range of 0 to $100 \%$ deforestation. In addition to testing for a "boom-bust" pattern, we also test for what we call conditional convergence (because the specification includes deforestation) by including the log of the HDI or the Income Index in the first year of the time period in our regression models. Convergence would be evidenced by a negative coefficient on the log of the initial level of HDI or the Income Index. Finally, we provide visual support for our results with maps of deforestation, the HDI and changes in the HDI for the Amazon Biome and the nation.

\section{RESULTS}

\section{(a) Amazon Analysis (Municipality Observations)}

Graphical analysis of the relationship between deforestation and development suggests that they were coupled before the decade of the 2000s. The highest rates of growth in HDI occurred in municipalities that were about $70 \%$ deforested, with slower growth in municipalities that had less deforestation and in those nearly fully deforested. However, HDI still increased in the most deforested municipalities (Figure 3A). In other words, rather than a bust, there was

\footnotetext{
${ }^{4}$ All regression models estimated using Stata 13.
} 
simply less boom, in what could be described as a "boom-pop" relationship. Moreover, in the 2000s (Figure 3B), we see a gain in income in municipalities at all levels of deforestation, with the greatest increases observed in municipalities with the highest levels of deforestation. ${ }^{5}$

(Figure 3 here)

In the regression analyses of HDI and the Income Index, we find deforestation by itself to have little explanatory power (R-squared of between 4 and 7\%), and in more recent years, we find the signs on deforestation coefficients to be opposite of what would be expected under a "boom-bust" pattern (Table 2, columns 1,3 and 5). Once we include the initial level of HDI in our model of conditional convergence, we find evidence of both convergence and a "boom-bust" pattern for 1991-2000 and 1991-2010 (Table 2, columns 2, 4 and 6). However in both cases, most of the explanatory power comes from the initial level of HDI, suggesting the importance of initial conditions in determining the growth of welfare and income. In the model of the Income Index (Table 3), we find similar results: in more recent years we find the signs on deforestation coefficients to be opposite of what would be expected under a "boom-bust" pattern and that most of the explanatory power comes from the initial level of HDI.

(Tables 2 and 3 here)

To assess whether our results are sensitive to our selection of municipalities, which replicates the study design of Rodrigues et al. (2009), we perform the same analysis for all 757

\footnotetext{
${ }^{5}$ All years present significant variation across deforestation classes (Kruskal-Wallis: $\left.\mathrm{P}<0.0001\right)$. The HDI growth is significantly faster in the last stage of deforestation relative the first stage $\operatorname{Pr}(|\mathrm{T}|>|\mathrm{t}|)=0.0045$ for the 1991-2000 and $\operatorname{Pr}(|\mathrm{T}|>|\mathrm{t}|)=0.0113$ for the $2000-2010$ changes.
} 
(of 783 municipalities) within the Brazilian Legal Amazon and with less than 5\% of their area covered by pixels of unknown status (Tables 4 and 5). We find no evidence of a "boom-bust" pattern in this sample (e.g., the coefficient on deforestation is negative) but do find evidence of convergence (e.g., the lagged log of the HDI and Income Index have positive and significant coefficients) with similar explanatory power in the models.

(Tables 4 and 5 here)

Figure 4 is based on regression estimates of the convergence coefficient, $\beta$ (Barro and Sala-I-Martin 1991) or the speed of conditional convergence for the HDI and the Income Index (not including deforestation as an explanatory variable). The figure shows the strong negative correlation between the growth rate from 1991 to 2010 and the log of the index at the start of the time period (Figures 3A and 3D); with weaker correlations in individual decades.

(Figure 4 here)

In sum, the evidence of a coupled "boom-bust pattern" of deforestation and development in cross-sectional data from 2000 (and from 1991, based on deforestation estimates extrapolated from state data) largely disappears in models estimated with panel data for the following decade. Instead, there is consistent strong support for conditional convergence, or the de-coupling of development and deforestation. Municipalities with relatively lower HDI and higher levels of deforestation in 1991 experienced greater growth in HDI over the decades to follow. Regression analysis of the HDI growth rate from 1991 to 2010 and the log of 1991 HDI reveals an R- 
squared of 0.83 (Figure 3A; 95\% confidence interval shaded in gray); suggesting that $83 \%$ of the variation in the rate of HDI growth can be explained by HDI levels in 1991. There is also consistent evidence of positive, but diminishing effects of deforestation on growth. This is the pattern that would be predicted by the "de-coupled" hypothesis: initial welfare levels have increasingly strong roles in explaining variation in growth rates as the economy becomes less dependent on natural resource inputs.

For interpretation, it is important to recall that these are models of the growth rates of HDI, rather than the levels. Conditional on initial levels of development, municipalities have higher rates of growth as the proportion of land deforested increases up to an inflection point of 70-80\%. After that point, growth slows, but importantly, it remains positive. Although a slowing of growth is observed in the most deforested municipalities, welfare does not decline, and HDI levels remain above those with more remaining forest area. In addition, the explanatory power of the deforestation variable is low relative to the initial HDI and Income Index. This is why we interpret the models as showing a "boom-pop" rather than a "boom-bust".

We also test for the boom-bust-recovery pattern identified in cross-sectional data by Celentano et al. (2012) ${ }^{6}$. In these estimations, we find the opposite of a boom-bust-recovery when the $\log$ of $1991 \mathrm{HDI}$ is included in the model. In this case, the coefficients on deforestation, deforestation-squared and deforestation-cubed are all significant but negative, positive and negative respectively. Together, these coefficients suggest that more growth occurs in municipalities with high levels of deforestation (between 25 and 75\%). However, the inclusion of deforestation-cubed does not improve the explanatory power of the models nor is it significant in the model that includes the $\log$ of $1991 \mathrm{HDI}^{7}$

\footnotetext{
${ }^{6}$ Results available upon request.

${ }^{7}$ The explanatory power for the models with deforestation-cubed are the same as in Table 2.
} 
We also test for convergence within the deforestation "classes" defined by Rodrigues et al. (2009): municipalities 0-25\% deforested in 2010 (classes A and B); >25-75\% (classes C-E) and $\mathbf{7 5 - 1 0 0 \%}$ (classes $\mathrm{F}$ and $\mathrm{G}$ ). This analysis provides robust support for convergence, independent of deforestation stage (Figure 1A, appendix). The initial HDI explains $82 \%$ of the variation in HDI growth from 2000 to 2010 for classes A and B (with deforestation < 25\%); 90\% of the variation in $2010 \mathrm{HDI}$ growth for classes C, D and $\mathrm{E}$ (with deforestation > 25\% and 75\%); and $92 \%$ of the variation in 2010 HDI growth for classes F and G (with deforestation > 75\%).

\section{(b) National Analysis (Municipality and Census Region Observations)}

In addition to identifying evidence of convergence in the Amazon, we also find support for a convergence pattern throughout the nation (Figure 5). Regression analysis reveals a robust inverse relationship between average HDI growth rates for 1991-2010 and the natural log of HDI in $1991\left(\mathrm{HDI}_{1991}\right)$ for all Brazilian municipalities, with an R-squared equal to 89\% (Figure 5A). Similar to the Amazon, we find evidence of a strong negative correlation between the growth rate from 1991 to 2010 and the log on the HDI and income indices (Figures 3A and 3D); with weaker correlation for each decade.

(Figure 5 here)

Examination of trends in HDI and income across census regions suggests convergence towards two different levels in southern and northern Brazil. Figure A2 (see the appendix) illustrates HDI $\sigma$ convergence (or convergence within regions) between the five official census regions in the country. Here, the North region contains all states that are located entirely in the 
Legal Amazon, but excludes Maranhão (in the Northeast) and Mato Grosso (in the Central West), which are only partially included in the Legal Amazon. The distribution of HDI across the major Brazilian regions shifts positively and becomes more tightly distributed around the mean over time, with the standard deviation declining from 0.10 in 1991 to 0.07 in 2010 resulting in the pattern noted in Figure A2A (in the appendix) and similar trends for the income index (Figure A2B) (see the appendix), but a marked difference between the northern and southern regions of the country.

\section{(c) Spatial Evidence of Convergence}

Last, we illustrate changes in deforestation and welfare in the Amazon with a map series depicting deforestation, HDI, and HDI change across municipalities in three time periods: 1991 (where deforestation data are derived from state values), 2000, and 2010 (Figures 6 and 7). ${ }^{8}$ The first sequence (Figure 6, A-C) presents forest cover loss for Amazonian municipalities. These figures employ diverging hues (green to brown) to differentiate the seven classes identified in Rodrigues et al. (2009) with a change in color (from green to tan/brown) for municipalities with forest cover loss greater than $40 \%$, given the importance of this value in the paper (i.e. where the bust occurs). Figures 6, D-F depict the HDI for Amazonian municipalities in the same time periods. Here the four HDI class intervals are based on an equal interval classification method using the minimum value in 1991 and maximum value in 2010 to define the range. These figures clearly demonstrate increasing HDI at the municipality level over time. A "boom-bust" pattern would result in lower HDI values located along the "arc of deforestation" or the region

\footnotetext{
${ }^{8}$ Map sequences were constructed in ESRI's ArcGIS software utilizing 2010 municipality boundaries for Brazil and the Legal Amazon obtained from Brazil's Institute of Geography and Statistics (IBGE). Municipality level deforestation and HDI data for the three time periods, 1991, 2000 and 2100 data were joined to the geographic data and classified to present temporal change.
} 
that is depicted by the 2010 deforestation map in tan and brown. However, this heavily deforested area actually has the highest HDI values in the 2000s. Convergence within the Amazon is illustrated by the large increases in HDI by decade in municipalities (Figure 6, G-I) with the lowest levels of HDI observed in 1991 (Figure 6D) and for the Amazon overall (Figure 6I. Municipality HDI change classes in the 1991-2000 and the 2000-2010 time periods were defined by the same equal intervals defined by the range between minimum value for changes between 1991 and 2000 and maximum values for changes between 2000 and 2010 . These figures show that the greatest increase in HDI has occurred in municipalities with a range of different deforestation levels.

Two final map series illustrate the HDI and changes in this value throughout the nation (Figure 7). The first sequence (Figure 7, A-C) depicts HDI for all Brazilian municipalities and shows increasing HDI over time. Here, as above, HDI intervals were determined based on an equal interval classification method using the minimum value in 1991 and maximum value in 2010 to define the range. Convergence is again vividly illustrated by the large increases in HDI (Figure 7, D-F), in the municipalities with the lowest HDI levels in 1991 (Figure 7A), both within and outside of the Amazon. Municipality HDI change classes in the 1991-2000 and the 2000-2010 time periods are equal intervals, based on the range between minimum value for changes between 1991 and 2000 and maximum values for changes between 2000 and 2010 . These maps show the biggest changes in HDI occurred in the southern part of the nation in the 1990s, but this relatively large increase in HDI moved to the northern part of the nation (including, but not limited to, the Amazon) in the decade to follow.

(Figures 6 and 7 here) 


\section{DISCUSSION}

The study of boom-bust cycles dates to the late 1800 s when this pattern was associated with boomtown industries in the American West (Graves, Weiler and Tynon 2009). The term was later associated with the economic business cycle, credit trends, and housing market changes linked to recessionary and expansionary periods of macroeconomic growth (Schumpeter 1954; Besomi 2006). Predictions of a similar fate for the Amazon were first put forward shortly after the development of "Operation Amazonia" by the military government. The irreversibility of deforestation and associated environmental degradation was expected to leave settlers with little choice but to become "poorer, hungrier, less philoprogenitive, and more nomadic" (Goodland and Irwin 1975)). The theoretical underpinning for this argument is that socioeconomic wellbeing is closely tied to-or coupled with- resource use.

While the boom-bust hypothesis is a prediction about how economies will develop over time, it has been tested with cross-sectional data on municipalities in the Brazilian Amazon (Rodrigues et al. 2009; Celentano et al. 2012). The results presented here, especially for the decade from 2000 to 2010, likely differ from previous findings because we use panel data. The mechanisms underlying the convergence processes likely influence the pattern that our results uncover. In a standard growth model, convergence occurs due to decreasing returns to shared capital, conditional on differences in saving rates, population growth and labor markets. Previous empirical studies have observed convergence due to shared physical capital (Liu 2009), transportation (Hashemi 2013), and technology (Frantzen 2004) between or within nations; and the shared legal institutions, currency, and fiscal policy that exist within a nation (DiCecio and Gascon 2010). Thus, it is the diffusion of these shared institutions that allow for the slower 
growing nations and states to catch up to their counterparts. While technological advances have impacted industry and education within Brazil, we also believe that conditional cash transfer programs in Brazil have contributed to the pattern of convergence revealed in this analysis. These programs were first introduced at the state level in the mid-1990s, federalized in 2001 and merged in 2003 to create Bolsa Familia, the world's largest program of its kind, and later expanded to include Bolsa Floresta (Barrientos 2013). Bolsa Familia provides relatively small cash transfers to poor families, who must provide evidence of school enrollment, child immunizations, and, if pregnant, pre-natal care (Shei 2013). Evaluations have found that the program reduces infant mortality and poverty rates (Rasella et al. 2013). Bolsa Floresta expanded the program to include payments to rural communities and families for the provision of ecosystem services.

Recent urbanization patterns have also likely played a role in convergence. While the fraction of the national population that is urban increased by $5.6 \%$ between 1991 to 2000 and by an additional $3.1 \%$ by 2010 , in the Legal Amazon, this fraction increased by $13.1 \%$ between 1991 to 2000 and by an additional 3.6\% by 2010 (Table 6). Thus, while the Amazon remains less urbanized ( $73 \%$ urban in 2010) than the rest of Brazil ( $84 \%$ urban in 2010), the urban population and the proportion of the population that is urban both grew much faster in the Amazon as compared to the country as a whole (Table 6). Furthermore, it appears that much of the gains in HDI occurred in municipalities where this urbanization has been the most rapid, as the correlation between the change in the percent urban (by municipality) and the change in the HDI, increased from 0.15 between 1991 and 2000 to 0.26 between 1991 and 2010.

(Table 6 here) 


\section{CONCLUSIONS}

The possibility of sustained development in the Brazilian Amazon has long been questioned, accompanied by dire predictions of ecosystem and economic collapse (Peres and Schneider 2012; Hecht and Cockburn 1990). Our results show that to date, deforestation has not been followed by economic decline. Instead we find compelling evidence that development in the Amazon is being driven by a "catch-up" effect, reinforced by economic growth that has made Brazil the world's $7^{\text {th }}$ largest economy (World Bank 2015). Federal programs aimed at regional development, poverty alleviation, and education (Silveira-Neto and Azzoni 2012; Fenwick 2009; Alston and Mueller 2011) have been found to reduce poverty, and thus may also have contributed to convergence of the municipalities in the Amazon with the rest of the country. While we find some evidence that deforestation is positively related to growth, the effects are small relative to other drivers of development, and diminish as deforested areas expand. We argue that neither the "boom-bust" nor "boom-bust-recovery" explain development patterns over time and that the neoclassical growth model, which has been used to model growth in many nations and regions, is a more likely explanation for the growth trajectory in the Amazon over the past couple decades.

Although forest clearing continues at a pace exceeding the 2020 target proposed to combat global climate change (INPE 2011), Brazil has made historic strides towards reducing deforestation. The nation currently employs the largest and most advanced real-time deforestation monitoring system in the world and has vastly expanded its protected area network (Walker et al. 2009; Nepstad et al. 2006; Nolte et al. 2013). Brazil has also been a key player in 
REDD+, committing to targets and taking a lead role in negotiations under the United Nations Framework Convention on Climate Change (UNFCCC) (Assunção et al. 2012).

Our findings suggest that while deforestation can be the basis for improvements in welfare through economic development, it need not be. Although deforested areas of the Amazon are growing rapidly relative to the rest of Brazil, and the municipality-level results suggest that the level of deforestation is positively associated with growth of the HDI, we find that both minimally and heavily deforested regions are experiencing large, measurable increases in wellbeing. Furthermore, we observe a considerably stronger negative effect of initial HDI on growth that holds at the national, municipality, and regional levels, but identify a clear distinction between the wealthier southern portion of the country (the South, Southeast and Central West census regions) and the poorer northern region (the North and Northeast census regions). While the northern regions are clearly catching up to the national average, they still have a long way to go. Together these findings suggest that the investment of REDD+ payments in policy measures aimed at directly improving welfare in poor forested regions, or at encouraging the transfer of skills and technology between regions, could potentially (and over the long run) counteract the immediate effects of any lost income from avoided deforestation. 


\section{References}

Abramovitz, M. 1986. “Catching Up, Forging Ahead, and Falling Behind.” The Journal of Economic History 46(2):385-406.

Alston, L.J., and B. Mueller. 2011. “Brazilian Development: This Time for Real?” CESifo Forum (1).

Assunção, J., C. Gandour, and R. Rocha. 2012. "Deforestation Slowdown in the Legal Amazon: Prices or Policies?" Climate Policy Initiative.

Barbier, E. 2005. Natural Resources and Economic Development. Cambridge University.

Barrientos, A. 2013. "The Rise of Social Assistance in Brazil." Development and Change 44(4):887-910.

Barro, R.J., and X. Sala-I-Martin. 1991. "Convergence across States and Regions.” Brookings Papers on Economic Activity (1):107-158.

Besomi, D. 2006. "Tendency to Equilibrium, the Possibility of Crisis, and the History of Business Cycle Theories." History of Economic Ideas 14(2):53-104.

Brando, P.M., D.C. Nepstad, E.A. Davidson, S.E. Trumbore, D. Ray, and P. Camargo. 2008. "Drought effects on litterfall, wood production and belowground carbon cycling in an Amazon forest: results of a throughfall reduction experiment." Philosophical Transactions of the Royal Society B: Biological Sciences 363(1498):1839-1848. 
Brondizio, E.S., and E.F. Moran. 2008. "Human dimensions of climate change: the vulnerability of small farmers in the Amazon." Philosophical Transactions of the Royal Society B: Biological Sciences 363(1498):1803-1809.

Celentano, D., E. Sills, M. Sales, and A. Veríssimo. 2012. "Welfare Outcomes and the Advance of the Deforestation Frontier in the Brazilian Amazon." World Development 40(4):850864.

Chhatre, A., S. Lakhanpal, A.M. Larson, F. Nelson, H. Ojha, and J. Rao. 2012. “Social safeguards and co-benefits in REDD+: a review of the adjacent possible." Current Opinion in Environmental Sustainability 4(6):654-660.

Davidson, E.A., A.C. de Araújo, P. Artaxo, J.K. Balch, I.F. Brown, M.M. C. Bustamante, M.T. Coe, R.S. DeFries, M. Keller, M. Longo, J.W. Munger, W. Schroeder, B.S. Soares-Filho, C.M. Souza, and S.C. Wofsy. 2012. "The Amazon basin in transition.” Nature 481(7381):321-328.

Davidson, E.A., and L.A. Martinelli. 2009. "Nutrient Limitations to Secondary Forest Growth." In M. Keller, J. Bustamente, J. Gash, and P. S. Dias, eds. Amazonia and Global Change. Geophysical Monograph Series. Washington D.C.: AGU, pp. 299-309.

Dawson, J.W., and M.C. Strazicich. 2010. “Time-Series Tests of Income Convergence with Two Structural Breaks: Evidence from 29 Countries.” Applied Economics Letters 17(79):909-912.

DiCecio, R., and C.S. Gascon. 2010. "Income Convergence in the United States: A Tale of Migration and Urbanization.” Annals of Regional Science 45(2):365-377. 
Duchelle, A.E., M. Cromberg, M.F. Gebara, R. Guerra, T. Melo, A. Larson, P. Cronkleton, J. Börner, E. Sills, S. Wunder, S. Bauch, P. May, G. Selaya, and W.D. Sunderlin. 2014. “Linking Forest Tenure Reform, Environmental Compliance, and Incentives: Lessons from REDD+ Initiatives in the Brazilian Amazon.” World Development 55:53-67.

Feddema, J.J., K.W. Oleson, G.B. Bonan, L.O. Mearns, L.E. Buja, G.A. Meehl, and W.M. Washington. 2005. “The Importance of Land-Cover Change in Simulating Future Climates.” Science 310(5754):1674-1678.

Fenwick, T.B. 2009. “Avoiding Governors: The Success of Bolsa Família.” Latin American Research Review 44(1):102-131.

Foley, J.A., G.P. Asner, M.H. Costa, M.T. Coe, R. DeFries, H.K. Gibbs, E.A. Howard, S. Olson, J. Patz, N. Ramankutty, and P. Snyder. 2007. “Amazonia revealed: forest degradation and loss of ecosystem goods and services in the Amazon Basin." Frontiers in Ecology and the Environment 5(1):25-32.

Frantzen, D. 2004. “Technological Diffusion and Productivity Convergence: A Study for Manufacturing in the OECD.” Southern Economic Journal 71(2):352-376.

Ghazoul, J., R.A. Butler, J. Mateo-Vega, and L.P. Koh. 2010. “REDD: a reckoning of environment and development implications." Trends in Ecology \& Evolution 25(7):396402.

Gibson, L., T.M. Lee, L.P. Koh, B.W. Brook, T.A. Gardner, J. Barlow, C.A. Peres, C.J.A. Bradshaw, W.F. Laurance, T.E. Lovejoy, and N.S. Sodhi. 2011. "Primary forests are irreplaceable for sustaining tropical biodiversity." Nature 478(7369):378-381. 
Godoy, R., V. Reyes-Garcia, V. Vadez, W.R. Leonard, S. Tanner, T. Huanca, and D. Wilkie. 2009. "The relation between forest clearance and household income among native Amazonians: Results from the Tsimane’ Amazonian panel study, Bolivia.” Ecological Economics 68(6):1864-1871.

Goodland, R.J.A., and H.S. Irwin. 1975. Amazon Jungle: Green Hell to Red Desert? An Ecological Discussion of the Environmental Impact of the Highway Construction Program in the Amazon Basin. Oxford: Elsevier Scientific Publishing Company.

Graves, P.E., S. Weiler, and E.E. Tynon. 2009. “The Economics of Ghost Towns.” Journal of Regional Analysis and Policy 39(2):131-140.

Guedes, G.R., E.S. Brondízio, A.F. Barbieri, R. Anne, R. Penna-Firme, and Á.O. D’Antona. 2012. "Poverty and Inequality in the Rural Brazilian Amazon: A Multidimensional Approach.” Human Ecology 40(1):41-57.

Guedes, G.R., L.K. VanWey, J.R. Hull, M. Antigo, and A.F. Barbieri. 2014. "Poverty dynamics, ecological endowments, and land use among smallholders in the Brazilian Amazon." Social Science Research 43:74-91.

Hashemi, F. 2013. "On the dynamics of convergence in cross-country incomes.” Economic Modelling 30(C):394-404.

Hecht, S., and A. Cockburn. 1990. The Fate of the Forest: Developers, Destroyers and Defenders of the Amazon. Harpercollins. 
Hess, L.L., J.M. Melack, E.M.L.M. Novo, C.C.F. Barbosa, and M. Gastil. 2003. "Dual-season mapping of wetland inundation and vegetation for the central Amazon basin." Remote Sensing of Environment 87(4):404-428.

IBGE. 2014. "Desenvolvimento Sustentável - Indicadores Ambientais e Sociais.” Series Historicas e Estatosticas Instituto Brasileiro de Geografia e Estatística.

IBGE. 2012. "Pesquisa Pecuária, Tabela 73 - Efetivo dos rebanhos por tipo de rebanho - Ano 1974 a 2010.” Instituto Brasileiro de Geografia e Estatística. Available at: http://www.sidra.ibge.gov.br/bda/acervo/.

INPE. 2000. "Monitoring the Brazilian Amazon Forest 1999/2000.” Available at: www.inpe.br.

INPE. 2007. “"Projeto Prodes Digital. Monitoramento da Floresta Amazonica Brasileira por Satelite' Disponivel no sitio da internet http://www.obt.inpe.br/prodes/. Dados acessado em abril de 2007. Sao Jose dos Campos, SP."

INPE. 2011. "Projeto Prodes: Monitoramento da Floresta Amazônica Brasileira por Satélite." National Institute for Space Research (INPE). Available at: http://www.obt.inpe.br/prodes/sisprodes2000_2010.htm.

Ioris, A.A.R. 2015. "The paradox of poverty in rich ecosystems: impoverishment and development in the Amazon of Brazil and Bolivia." The Geographical Journal:n/a-n/a.

Laurance, W.F., P.M. Fearnside, S.G. Laurance, P. Delamonica, T.E. Lovejoy, J.M. Rankin-de Merona, J.Q. Chambers, and C. Gascon. 1999. "Relationship between soils and Amazon 
forest biomass: a landscape-scale study.” Forest Ecology and Management 118(13):127-138.

Lei, C.K., and P.S. Tam. 2010. “A Panel Data Approach to the Income Convergence among Mainland China, Hong Kong and Macao.” Journal of the Asia Pacific Economy 15(4):420-435.

Lin, L., S.K. Pattanayak, E.O. Sills, and W.D. Sunderlin. 2012. "Site selection for forest carbon projects.” In A. Angelsen, M. Brockhaus, W. D. Sunderlin, and L. V. Verchot, eds. Analysing REDD: Challenges and choices. Bogor, Indonesia: CIFOR.

Liu, X. 2009. “Trade and Income Convergence: Sorting Out the Causality.” Journal of International Trade and Economic Development 18(1):169-195.

Lu, D., E. Moran, and P. Mausel. 2002. "Linking Amazonian secondary succession forest growth to soil properties." Land Degradation \& Development 13(4):331-343.

May, P.H., B. Millikan, and M.. Gebara. 2011. "The context of REDD+ in Brazil: Drivers, agents, and institutions.” No. 55, Center for International Forestry Research (CIFOR).

Nepstad, D.C., A. Verissimo, A. Alencar, C. Nobre, E. Lima, P. Lefebvre, P. Schlesinger, C. Potter, P. Moutinho, E. Mendoza, M. Cochrane, and V. Brooks. 1999. "Large-scale impoverishment of Amazonian forests by logging and fire.” Nature 398(6727):505-508.

Nepstad, D., S. Schwartzman, B. Bamberger, M. Santilli, D. Ray, P. Schlesinger, P. Lefebvre, A. Alencar, E. Prinz, G. Fiske, and A. Rolla. 2006. "Inhibition of Amazon Deforestation and Fire by Parks and Indigenous Lands.” Conservation Biology 20(1):65-73. 
Nobre, A.D. 2014. “O Futuro Climático da Amazônia: Relatório de Avaliação Científica.” INPE - Instituto Nacional de Pesquisas Espaciais.

Nogueira, E.M., P.M. Fearnside, B.W. Nelson, R.I. Barbosa, and E.W.H. Keizer. 2008. "Estimates of forest biomass in the Brazilian Amazon: New allometric equations and adjustments to biomass from wood-volume inventories." Forest Ecology and Management 256(11):1853-1867.

Nolte, C., A. Agrawal, K.M. Silvius, and B.S. Soares-Filho. 2013. "Governance regime and location influence avoided deforestation success of protected areas in the Brazilian Amazon." Proceedings of the National Academy of Sciences 110(13):4956-4961.

Peres, C.A., and M. Schneider. 2012. "Subsidized agricultural resettlements as drivers of tropical deforestation." Biological Conservation 151(1):65-68.

PNUD. 2013. "Desenvolvimento Humano e IDH.” Programa das Nações Unidas para o Desenvolvimento. Available at: http://www.pnud.org.br/IDH/DH.aspx [Accessed December 18, 2013].

Rasella, D., R. Aquino, C.A.T. Santos, R. Paes-Sousa, and M.L. Barreto. 2013. "Effect of a conditional cash transfer programme on childhood mortality: a nationwide analysis of Brazilian municipalities." Lancet 382(9886):57-64.

Rodrigues, A., R. Ewers, L. Parry, C. Souza, A. Verissimo, and A. Balmford. 2009. "Boom-andBust Development Patterns Across the Amazon Deforestation Frontier.” Science 324(5933):1435-1437. 
Sala-i-Martin, X. 2006. "The World Distribution of Income: Falling Poverty and ...

Convergence, Period.” Quarterly Journal of Economics 121(2):351-397.

Schumpeter, J.A. 1954. History of Economic Analysis. London: Allen \& Unwin.

Shei, A. 2013. “Brazil's Conditional Cash Transfer Program Associated With Declines In Infant Mortality Rates." Health Affairs 32(7):1274-1281.

Sills, E.O., S. Atmadja, C. de Sassi, A.E. Duchelle, D. Kweka, I.A.P. Resosudarmo, and W.D. Sunderlin eds. 2014. REDD+ on the ground: A case book of subnational initiatives across the globe. Bogor, Indonesia: CIFOR, Center for International Forestry Research. Available at: http://www.cifor.org/library/5202/redd-on-the-ground-a-case-book-ofsubnational-initiatives-across-the-globe/ [Accessed December 17, 2014].

Silveira-Neto, R.M., and C.R. Azzoni. 2012. "Social Policy as Regional Policy: Market and Nonmarket Factors Determining Regional Inequality.” Journal of Regional Science $52(3): 433-450$.

Uriarte, M., M. Pinedo-Vasquez, R.S. DeFries, K. Fernandes, V. Gutierrez-Velez, W.E. Baethgen, and C. Padoch. 2012. "Depopulation of rural landscapes exacerbates fire activity in the western Amazon." Proceedings of the National Academy of Sciences 109(52):21546-21550.

USDA. 2013. "Livestock and Poultry: World Markets and Trade." United States Department of Agriculture, Foreign Agricultural Service, Office of Global Analysis. 
Walker, R., N.J. Moore, E. Arima, S. Perz, C. Simmons, M. Caldas, D. Vergara, and C. Bohrer. 2009. "Protecting the Amazon with protected areas." Proceedings of the National Academy of Sciences 106(26):10582-10586.

World Bank (2015) "World DataBank: World Development Indicators, GDP" http://databank.worldbank.org/data/ 
Table 1: Municipal HDI and Deforestation Ratio of Municipalities in the Legal Amazon, summarized by State

\begin{tabular}{|c|c|c|c|c|c|c|c|c|c|}
\hline & \multicolumn{3}{|c|}{1991} & \multicolumn{3}{|c|}{2000} & \multicolumn{3}{|c|}{2010} \\
\hline & $\mathrm{HDI}$ & $\begin{array}{l}\text { Income } \\
\text { Index }\end{array}$ & $\begin{array}{c}\text { Deforestation } \\
\text { Ratio }\end{array}$ & HDI & $\begin{array}{l}\text { Income } \\
\text { Index }\end{array}$ & $\begin{array}{c}\text { Deforestation } \\
\text { Ratio } \\
\end{array}$ & HDI & $\begin{array}{l}\text { Income } \\
\text { Index }\end{array}$ & $\begin{array}{c}\text { Deforestation } \\
\text { Ratio }\end{array}$ \\
\hline Acre $(n=22)$ & $\begin{array}{c}0.28 \\
(0.08)\end{array}$ & $\begin{array}{c}0.47 \\
(0.07)\end{array}$ & $\begin{array}{c}0.05 \\
(0.05)\end{array}$ & $\begin{array}{c}0.42 \\
(0.08)\end{array}$ & $\begin{array}{c}0.51 \\
(0.08)\end{array}$ & $\begin{array}{c}0.17 \\
(0.17)\end{array}$ & $\begin{array}{c}0.59 \\
(0.06)\end{array}$ & $\begin{array}{c}0.59 \\
(0.06)\end{array}$ & $\begin{array}{c}0.24 \\
(0.23)\end{array}$ \\
\hline $\begin{array}{l}\text { Amazonas } \\
(n=57)\end{array}$ & $\begin{array}{c}0.30 \\
(0.07)\end{array}$ & $\begin{array}{c}0.47 \\
(0.06)\end{array}$ & $\begin{array}{c}0.01 \\
(0.01)\end{array}$ & $\begin{array}{c}0.40 \\
(0.06)\end{array}$ & $\begin{array}{c}0.49 \\
(0.06)\end{array}$ & $\begin{array}{c}0.03 \\
(0.04)\end{array}$ & $\begin{array}{c}0.56 \\
(0.05)\end{array}$ & $\begin{array}{c}0.54 \\
(0.05)\end{array}$ & $\begin{array}{c}0.04 \\
(0.05)\end{array}$ \\
\hline Amapa (n=8) & $\begin{array}{c}0.33 \\
(0.07)\end{array}$ & $\begin{array}{c}0.51 \\
(0.08)\end{array}$ & $\begin{array}{c}0.01 \\
(0.01)\end{array}$ & $\begin{array}{c}0.48 \\
(0.05)\end{array}$ & $\begin{array}{c}0.54 \\
(0.04)\end{array}$ & $\begin{array}{c}0.02 \\
(0.03)\end{array}$ & $\begin{array}{l}0.64 \\
(0.04)\end{array}$ & $\begin{array}{c}0.61 \\
(0.04)\end{array}$ & $\begin{array}{c}0.03 \\
(0.03)\end{array}$ \\
\hline $\begin{array}{l}\text { Maranhao } \\
(n=91)\end{array}$ & $\begin{array}{c}0.26 \\
(0.07)\end{array}$ & $\begin{array}{c}0.41 \\
(0.05)\end{array}$ & $\begin{array}{c}0.20 \\
(0.15)\end{array}$ & $\begin{array}{c}0.39 \\
(0.06)\end{array}$ & $\begin{array}{c}0.45 \\
(0.05)\end{array}$ & $\begin{array}{c}0.50 \\
(0.38)\end{array}$ & $\begin{array}{c}0.58 \\
(0.05)\end{array}$ & $\begin{array}{c}0.53 \\
(0.05)\end{array}$ & $\begin{array}{c}0.76 \\
(0.22)\end{array}$ \\
\hline $\begin{array}{l}\text { Mato Grosso } \\
(n=66)\end{array}$ & $\begin{array}{c}0.37 \\
(0.06)\end{array}$ & $\begin{array}{c}0.58 \\
(0.07)\end{array}$ & $\begin{array}{c}0.10 \\
(0.06)\end{array}$ & $\begin{array}{c}0.53 \\
(0.05)\end{array}$ & $\begin{array}{c}0.63 \\
(0.05)\end{array}$ & $\begin{array}{c}0.42 \\
(0.27)\end{array}$ & $\begin{array}{c}0.68 \\
(0.03)\end{array}$ & $\begin{array}{c}0.68 \\
(0.03)\end{array}$ & $\begin{array}{c}0.52 \\
(0.24)\end{array}$ \\
\hline Para $(n=94)$ & $\begin{array}{c}0.30 \\
(0.06)\end{array}$ & $\begin{array}{c}0.49 \\
(0.06)\end{array}$ & $\begin{array}{c}0.11 \\
(0.09)\end{array}$ & $\begin{array}{c}0.42 \\
(0.07)\end{array}$ & $\begin{array}{c}0.54 \\
(0.07)\end{array}$ & $\begin{array}{c}0.36 \\
(0.29)\end{array}$ & $\begin{array}{c}0.58 \\
(0.06)\end{array}$ & $\begin{array}{c}0.58 \\
(0.06)\end{array}$ & $\begin{array}{c}0.46 \\
(0.31)\end{array}$ \\
\hline $\begin{array}{l}\text { Rondonia } \\
(n=50)\end{array}$ & $\begin{array}{c}0.31 \\
(0.08)\end{array}$ & $\begin{array}{c}0.50 \\
(0.07)\end{array}$ & $\begin{array}{c}0.11 \\
(0.06)\end{array}$ & $\begin{array}{c}0.47 \\
(0.06)\end{array}$ & $\begin{array}{c}0.61 \\
(0.04)\end{array}$ & $\begin{array}{c}0.48 \\
(0.27)\end{array}$ & $\begin{array}{c}0.64 \\
(0.04)\end{array}$ & $\begin{array}{c}0.66 \\
(0.04)\end{array}$ & $\begin{array}{c}0.57 \\
(0.25)\end{array}$ \\
\hline Roraima ( $n=9)$ & $\begin{array}{c}0.33 \\
(0.04)\end{array}$ & $\begin{array}{c}0.51 \\
(0.07)\end{array}$ & $\begin{array}{c}0.03 \\
(0.03)\end{array}$ & $\begin{array}{c}0.50 \\
(0.04)\end{array}$ & $\begin{array}{c}0.55 \\
(0.04)\end{array}$ & $\begin{array}{c}0.07 \\
(0.08)\end{array}$ & $\begin{array}{c}0.61 \\
(0.06)\end{array}$ & $\begin{array}{c}0.57 \\
(0.06)\end{array}$ & $\begin{array}{c}0.11 \\
(0.11)\end{array}$ \\
\hline $\begin{array}{l}\text { Tocantins } \\
(n=26)\end{array}$ & $\begin{array}{c}0.30 \\
(0.06)\end{array}$ & $\begin{array}{c}0.47 \\
(0.06)\end{array}$ & $\begin{array}{c}0.39 \\
(0.05)\end{array}$ & $\begin{array}{c}0.45 \\
(0.05)\end{array}$ & $\begin{array}{c}0.53 \\
(0.07)\end{array}$ & $\begin{array}{c}0.79 \\
(0.10)\end{array}$ & $\begin{array}{c}0.64 \\
(0.04)\end{array}$ & $\begin{array}{c}0.60 \\
(0.05)\end{array}$ & $\begin{array}{c}0.83 \\
(0.09)\end{array}$ \\
\hline Total $(n=423)$ & $\begin{array}{c}0.30 \\
(0.07)\end{array}$ & $\begin{array}{c}0.48 \\
(0.08)\end{array}$ & $\begin{array}{c}0.12 \\
(0.13)\end{array}$ & $\begin{array}{c}0.44 \\
(0.08)\end{array}$ & $\begin{array}{c}0.53 \\
(0.09)\end{array}$ & $\begin{array}{c}0.38 \\
(0.33)\end{array}$ & $\begin{array}{c}0.60 \\
(0.06)\end{array}$ & $\begin{array}{c}0.59 \\
(0.07)\end{array}$ & $\begin{array}{c}0.49 \\
(0.34)\end{array}$ \\
\hline
\end{tabular}

Notes: Standard deviation in parenthesis 
Table 2: Estimation of Percent Change in HDI in Brazilian Municipalities in the Amazon Biome (>70\% mature forest cover in 1960)

\begin{tabular}{lcccccc}
\hline & \multicolumn{5}{c}{ \% Change in Human Development Index (HDI) from $\mathrm{T}_{0}$ to $\mathrm{T}_{1}$} \\
\cline { 2 - 6 } & $1991-2000$ & $1991-2000$ & $2000-2010$ & $2000-2010$ & $1991-2010$ & $1991-2010$ \\
\cline { 2 - 6 } Constant & $0.405^{* * *}$ & $2.584^{* * *}$ & $0.416^{* * *}$ & $2.955^{* * *}$ & $0.691^{* * *}$ & $6.115^{* * *}$ \\
& $(0.020)$ & $(0.102)$ & $(0.014)$ & $(0.065)$ & $(0.019)$ & $(0.110)$ \\
Deforestation & $0.322^{* *}$ & $0.507^{* * *}$ & $-0.255^{* * *}$ & $0.166^{* * *}$ & $-0.189^{*}$ & $0.006^{* * *}$ \\
(Ratio in $\left.\mathrm{T}_{1}\right)^{\psi}$ & $(0.126)$ & $(0.087)$ & $(0.078)$ & $(0.038)$ & $(0.102)$ & $(0.001)$ \\
Deforestation & -0.159 & $-0.418^{* * *}$ & $0.301^{* * *}$ & $-0.119^{* * *}$ & $0.319^{* * *}$ & $-0.005^{* * *}$ \\
(Ratio in $\left.\mathrm{T}_{1}\right)^{2}$ & $(0.139)$ & $(0.096)$ & $(0.080)$ & $(0.039)$ & $(0.105)$ & $(0.001)$ \\
Log & & $-0.646^{* * *}$ & & $-0.689^{* * *}$ & & $-1.528^{* * *}$ \\
(Index in $\left.\mathrm{T}_{0}\right)$ & & $(0.030)$ & & $(0.018)$ & & $(0.032)$ \\
R-Squared & 0.07 & 0.56 & 0.04 & 0.80 & 0.06 & 0.85 \\
Observations & 423 & 423 & 423 & 423 & 423 & 423 \\
\hline
\end{tabular}

Notes: Standard errors in parenthesis; ${ }^{*}, * *$, and ${ }^{* * *}$ indicate significant at $10 \% ; 5 \%$; and $1 \%$ levels, respectively

${ }^{\Psi}$ The deforestation ratio is the ratio of the deforested area to the total land area in the ending time period (the cumulative deforestation at the time period end)

Table 3: Estimation of Percent Change in Income in Brazilian Municipalities in the Amazon Biome (>70\% mature forest cover in 1960)

\begin{tabular}{lcccccc}
\hline & \multicolumn{5}{c}{$\%$ Change in Income Index $\left(\mathrm{HDI}_{\text {Income }}\right)$ from $\mathrm{T}_{0}$ to $\mathrm{T}_{1}$} \\
\cline { 2 - 6 } & $1991-2000$ & $1991-2000$ & $2000-2010$ & $2000-2010$ & $1991-2010$ & $1991-2010$ \\
\cline { 2 - 6 } Constant & $0.067^{* * *}$ & $1.022^{* * *}$ & $0.118^{* * *}$ & $1.589^{* * *}$ & $0.173^{* * *}$ & $2.255^{* * *}$ \\
& $(0.010)$ & $(0.119)$ & $(0.009)$ & $(0.078)$ & $(0.014)$ & $(0.112)$ \\
Deforestation & $0.259^{* * *}$ & $0.372^{* * *}$ & $-0.150^{* * *}$ & $0.103^{* * *}$ & $0.001^{*}$ & $0.004^{* * *}$ \\
(Ratio in $\left.\mathrm{T}_{1}\right)^{\psi}$ & $(0.061)$ & $(0.059)$ & $(0.049)$ & $(0.039)$ & $(0.001)$ & $(0.001)$ \\
Deforestation & $-0.226^{* * *}$ & $-0.361^{* * *}$ & $0.208^{* * *}$ & -0.064 & 0.00 & $-0.003^{* * *}$ \\
(Ratio in $\left.\mathrm{T}_{1}\right)^{2}$ & $(0.068)$ & $(0.065)$ & $(0.051)$ & $(0.040)$ & $(0.001)$ & $(0.001)$ \\
Log & & $-0.249^{* * *}$ & & $-0.378^{* * *}$ & & $-0.542^{* * *}$ \\
(Index in $\left.\mathrm{T}_{0}\right)$ & & $(0.022)$ & & $(0.092)$ & & $(0.031)$ \\
R-Squared & 0.05 & 0.18 & 0.07 & 0.50 & 0.01 & 0.51 \\
Observations & 423 & 423 & 423 & 423 & 423 & 423 \\
\hline
\end{tabular}

Notes: Standard errors in parenthesis; ${ }^{*}, * *$, and ${ }^{* *}$ indicate significant at $10 \% ; 5 \%$; and $1 \%$ levels, respectively

${ }^{\Psi}$ The deforestation ratio is the ratio of the deforested area to the total land area in the ending time period (the cumulative deforestation at the time period end) 
Table 4: Robustness Checks- Estimation of Percent Change Rates for All Amazonian Municipalities

\begin{tabular}{lcccccc}
\hline & \multicolumn{5}{c}{ \% Change in Human Development Index (HDI) from $\mathrm{T}_{0}$ to $\mathrm{T}_{1}$} \\
\cline { 2 - 6 } & $1991-2000$ & $1991-2000$ & $2000-2010$ & $2000-2010$ & $1991-2010$ & $1991-2010$ \\
\cline { 2 - 6 } Constant & $2.949 * * *$ & $1.055^{* * *}$ & $0.392^{* * *}$ & $2.898^{* * *}$ & $0.457^{* * *}$ & $6.567^{* * *}$ \\
& $(0.051)$ & $(0.029)$ & $(0.009)$ & $(0.082)$ & $(0.014)$ & $(0.094)$ \\
Deforestation & -0.006 & -0.245 & $-0.158^{* * *}$ & $0.247^{* * *}$ & 0.164 & 0.121 \\
(Ratio in $\left.\mathrm{T}_{1}\right)^{\psi}$ & $(0.027)$ & $(0.188)$ & $(0.056)$ & $(0.072)$ & $(0.106)$ & $(0.079)$ \\
Deforestation & 0.014 & $0.472^{* *}$ & $0.219^{* * *}$ & $-0.243^{* * *}$ & -0.061 & -0.133 \\
(Ratio in $\left.\mathrm{T}_{1}\right)^{2}$ & $(0.030)$ & $(0.209)$ & $(0.062)$ & $(0.085)$ & $(0.126)$ & $(0.089)$ \\
Log & & $-0.715^{* * *}$ & & $-0.676^{* * *}$ & & $-1.615^{* * *}$ \\
(Index in $\left.\mathrm{T}_{0}\right)$ & & $(0.024)$ & & $(0.013)$ & & $(0.027)$ \\
R-Squared & 0.02 & 0.78 & 0.02 & 0.55 & 0.02 & 0.83 \\
Observations & 757 & 757 & 757 & 757 & 757 & 757 \\
\hline
\end{tabular}

Notes: Standard errors in parenthesis; *, ${ }^{* *}$, and ${ }^{* * *}$ indicate significant at $10 \% ; 5 \%$; and $1 \%$ levels, respectively

${ }^{\Psi}$ The deforestation ratio is the ratio of the deforested area to the total land area in the ending time period (the cumulative deforestation at the time period end).

Table 5: Robustness Checks- Estimation of Growth Rates for All Amazonian Municipalities

\begin{tabular}{lcccccc}
\hline & \multicolumn{5}{c}{$\%$ Change in Income Index $\left(\mathrm{HDI}_{\text {Income }}\right)$ from $\mathrm{T}_{0}$ to $\mathrm{T}_{1}$} \\
\cline { 2 - 6 } & $1991-2000$ & $1991-2000$ & $2000-2010$ & $2000-2010$ & $1991-2010$ & $1991-2010$ \\
\cline { 2 - 7 } Constant & $1.642^{* * *}$ & $0.241^{* * *}$ & $0.130^{* * *}$ & $1.100^{* * *}$ & $0.103^{* * *}$ & $2.526^{* * *}$ \\
& $(0.060)$ & $(0.009]$ & $(0.006)$ & $(0.082)$ & $(0.006)$ & $(0.083)$ \\
Deforestation & 0.005 & 0.012 & $-0.082^{* *}$ & $0.154^{* * *}$ & $0.096^{* *}$ & $0.100^{* *}$ \\
(Ratio in $\left.\mathrm{T}_{1}\right)^{\psi}$ & $(0.027)$ & $(0.058]$ & $(0.036)$ & $(0.042)$ & $(0.046)$ & $(0.041)$ \\
Deforestation & -0.004 & 0.04 & $0.115^{* * *}$ & $-0.166^{* * *}$ & -0.087 & $-0.106^{* *}$ \\
(Ratio in $\left.\mathrm{T}_{1}\right)^{2}$ & $(0.030)$ & $(0.064]$ & $(0.041)$ & $(0.050)$ & $(0.054)$ & $(0.046)$ \\
Log & & $-0.259^{* * *}$ & & $-0.382^{* * *}$ & & $-0.591^{* * *}$ \\
(Indexin $\left.\mathrm{T}_{0}\right)$ & & $(0.021]$ & & $(0.015)$ & & $(0.022)$ \\
R-Squared & 0.46 & 0.01 & 0.01 & 0.17 & 0.01 & 0.51 \\
Observations & 757 & 757 & 757 & 757 & 757 & 757 \\
\hline
\end{tabular}

Notes: Standard errors in parenthesis; ${ }^{*}, * *$, and $* * *$ indicate significant at $10 \% ; 5 \%$; and $1 \%$ levels, respectively

${ }^{\Psi}$ The deforestation ratio is the ratio of the deforested area to the total land area in the ending time period (the cumulative deforestation at the time period end). 
Table 6: Total Population, Percent Change in the Population and Urban Percentage in the Nation, Legal Amazon, and Amazon Sample (1991-2010)

\begin{tabular}{|c|c|c|c|c|c|}
\hline & 1991 & 2000 & 2010 & $\begin{array}{c}\text { Percent } \\
\text { Change } \\
1991-2000 \\
\end{array}$ & $\begin{array}{c}\text { Percent } \\
\text { Change } \\
2000-2010\end{array}$ \\
\hline Brazil Population $^{1}$ & $146,825,475$ & $169,872,856$ & $190,755,799$ & 15.70 & 12.29 \\
\hline Urban Population & $110,990,990$ & $137,925,238$ & $160,934,649$ & 24.27 & 16.68 \\
\hline Rural Population & $35,834,485$ & $31,947,618$ & $29,821,150$ & -10.85 & -6.66 \\
\hline Percent Urban & 75.59 & 81.19 & 84.37 & 5.60 & 3.17 \\
\hline Legal Amazon Population ${ }^{2}$ & $15,802,024$ & $19,784,344$ & $23,955,338$ & 25.20 & 21.08 \\
\hline Urban Population & $8,818,084$ & $13,631,358$ & $17,367,710$ & 54.58 & 27.41 \\
\hline Rural Population & $7,002,953$ & $6,165,236$ & $6,598,074$ & -11.96 & 7.02 \\
\hline Percent Urban & 55.80 & 68.90 & 72.50 & 13.10 & 3.60 \\
\hline Amazon Sample Population ${ }^{3}$ & $8,585,487$ & $10,881,615$ & $13,317,665$ & 26.74 & 22.39 \\
\hline Urban Population & $4,718,243$ & $6,813,792$ & $9,045,728$ & 44.41 & 32.76 \\
\hline Rural Population & $3,885,644$ & $4,081,559$ & $4,283,393$ & 5.04 & 4.95 \\
\hline Percent Urban & 54.96 & 62.62 & 67.92 & 7.66 & 5.31 \\
\hline \multicolumn{6}{|c|}{$\begin{array}{l}{ }^{1} \text { Source: IBGE - Banco de Dados Agredados "Tabela } 200 \text { - População residente por sexo, situação e grupos de idade - Amostra - } \\
\text { Características Gerais da População" http://www.sidra.ibge.gov.br/bda/acervo/ accessed January } 2015 \text {. } \\
\text { 2Includes } 757 \text { municipalities within the Legal Amazon } 95 \% \text { or more of their area covered by pixels of known status; see Tables } 5 \\
\text { and } 6 . \\
3 \\
3 \text { Includes } 423 \text { municipalities that had at least } 70 \% \text { mature forest cover in } 1960 \text { and had } 95 \% \text { or more of their area covered by } \\
\text { pixels of known status. }\end{array}$} \\
\hline
\end{tabular}




\section{Appendix A - Additional Graphical Evidence}

A

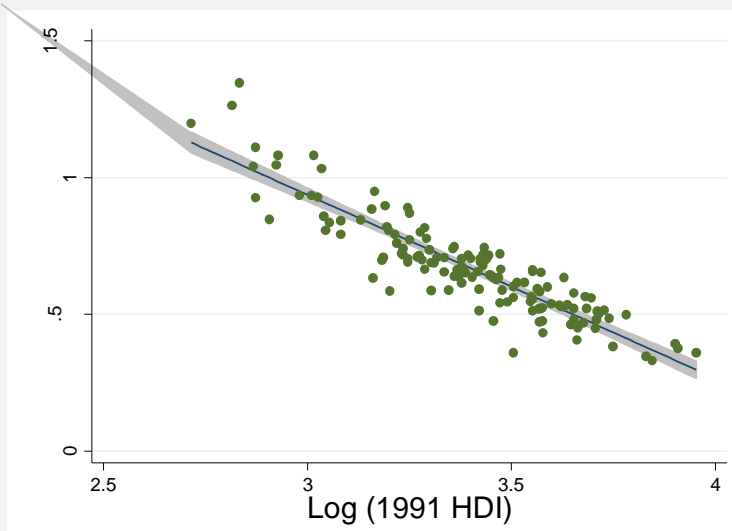

B

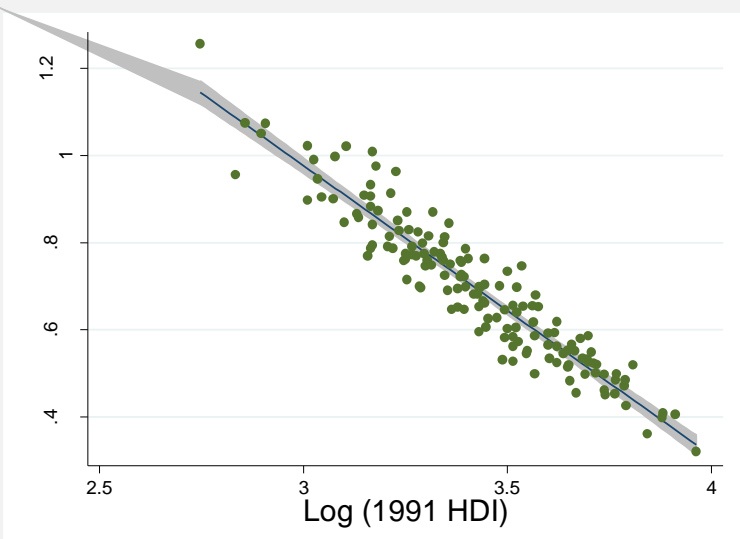

C

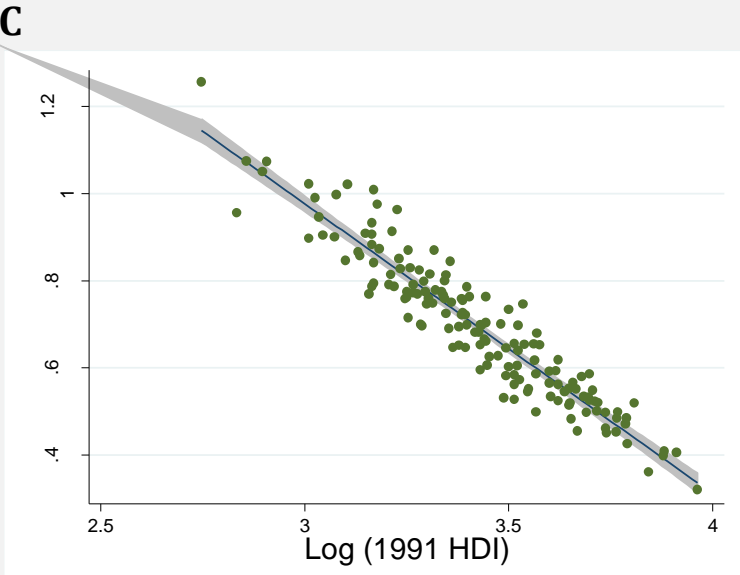

Figure A1. Evidence of convergence in HDI among Amazonian municipalities in our sample $(n=423)$. Each graph plots the annual growth rate of HDI relative to the $\log$ of HDI in 1991, 95\% confidence interval shaded in gray. (A) Includes deforestation classes A and B, 2010 deforestation 0-25\%; R-squared $=0.8225$ (B) Includes deforestation classes C-E, 2010 deforestation $>25-75 \%$; $\mathrm{R}$-squared $=0.8945$ (C) Includes deforestation classes $\mathrm{F}$ and G, 2010 deforestation $>25-75 \%$; R-squared $=0.9195$ 
A. HDI by Census Region (1991-2010)

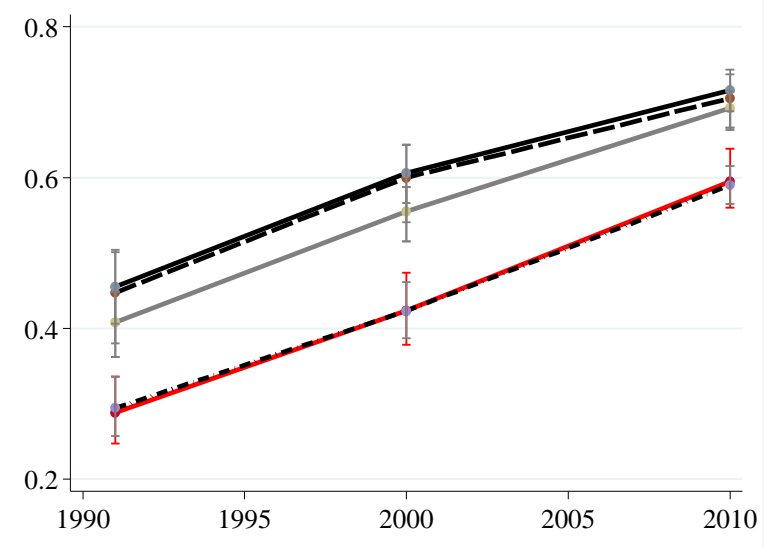

B. Income Index by Census Region (1991-2010)

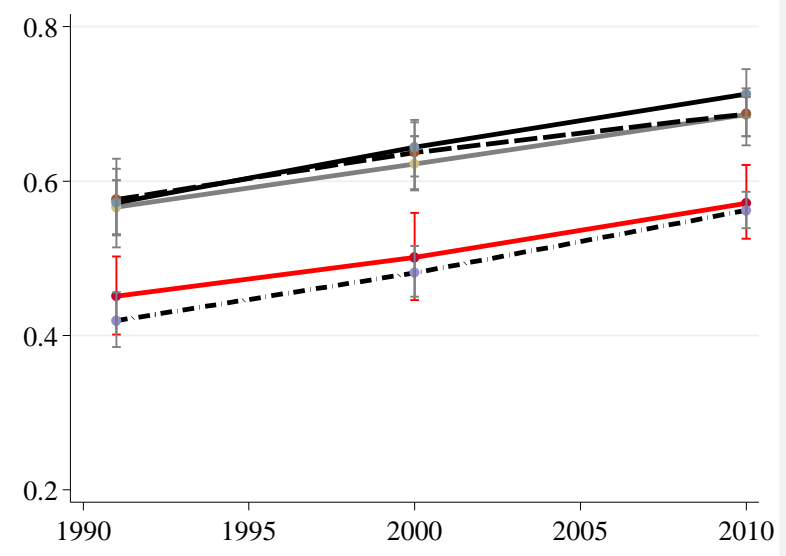

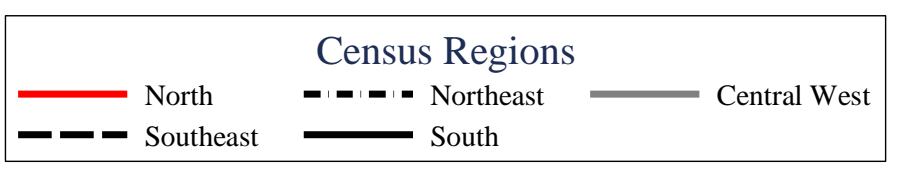

Figure A2. Evidence of $\sigma$ convergence: The HDI living standard index and the income index median by census region over time; bars indicate first and third quartiles 
A

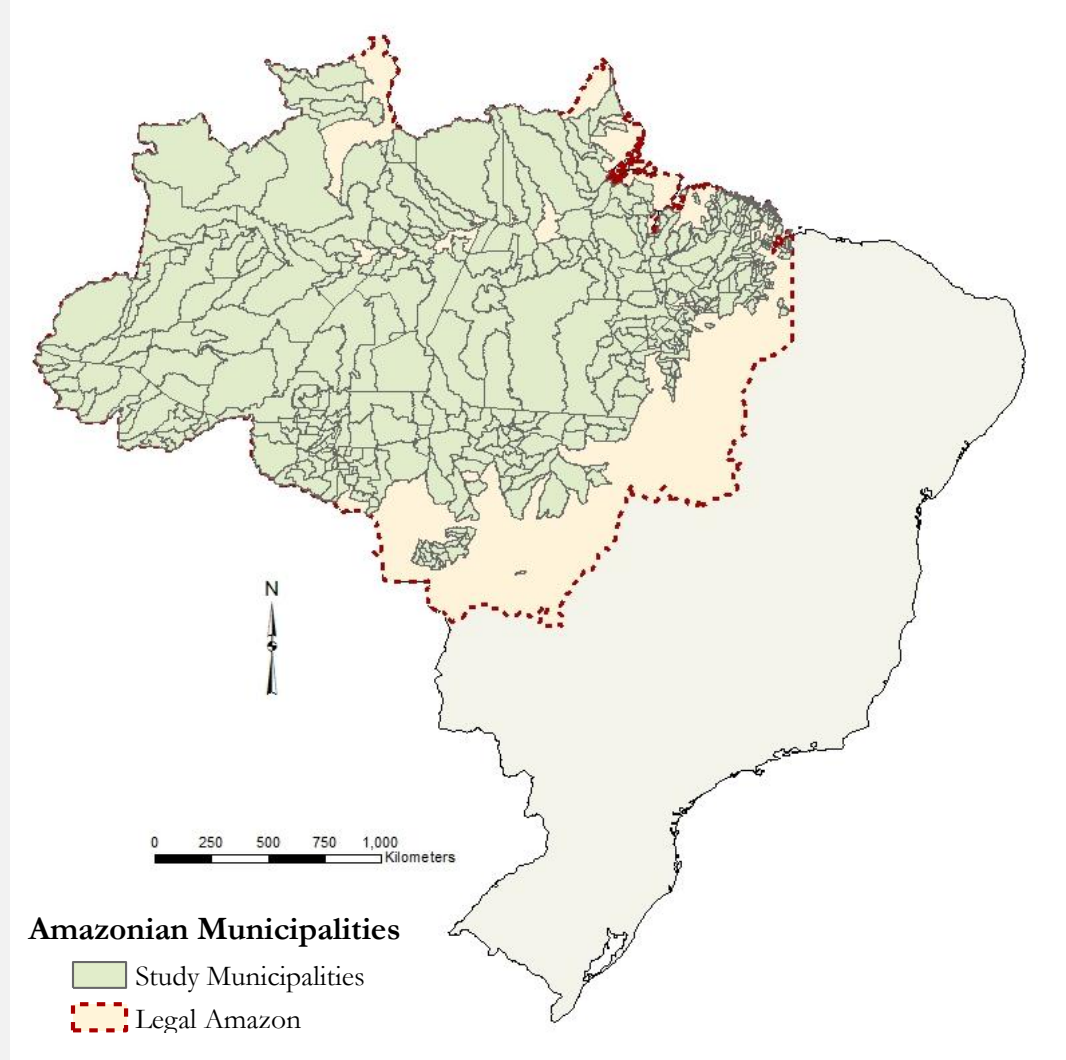

B

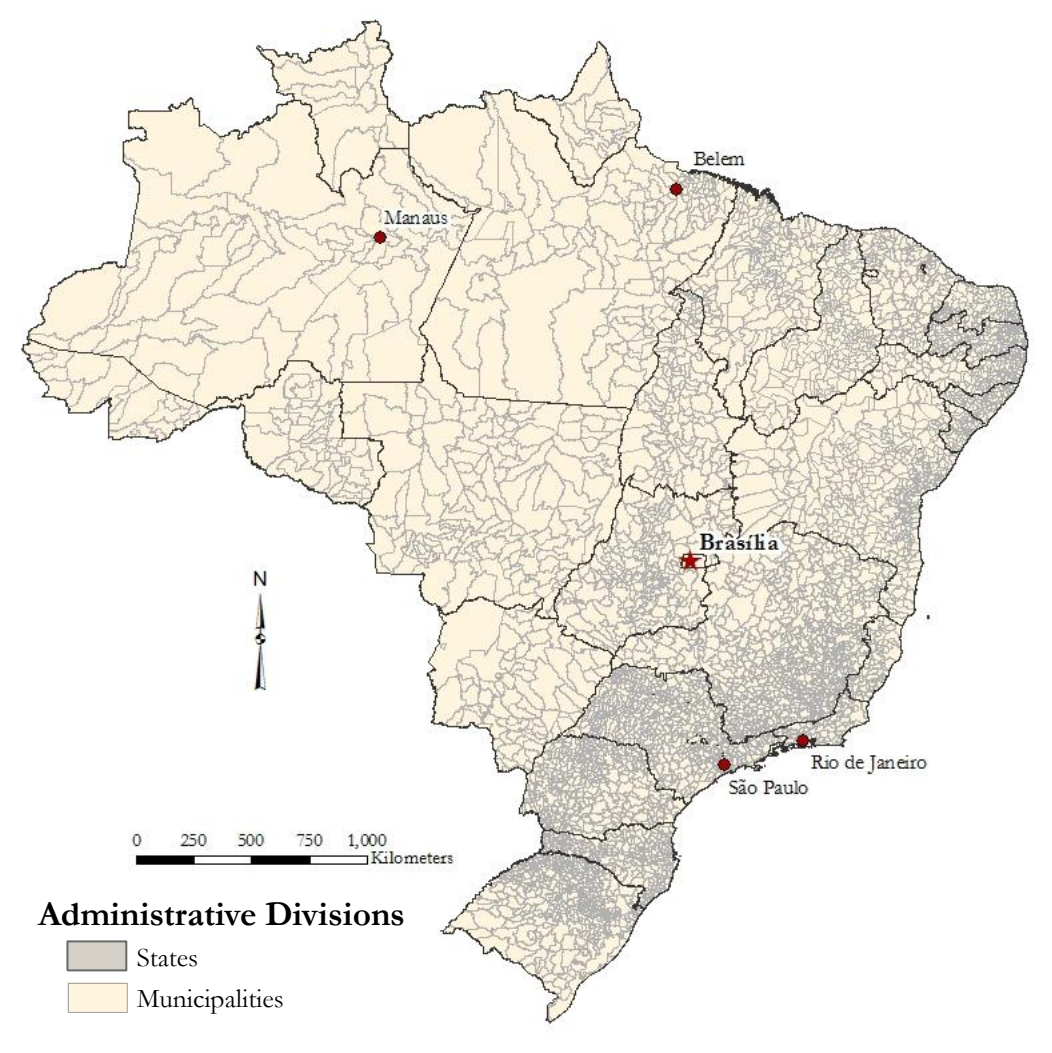

Figure 1: Study areas: (A) Municipalities in the Legal Amazon with at least $70 \%$ original forest cover $(n=423)$ (B) All municipalities within Brazil $(n=5565)$. 


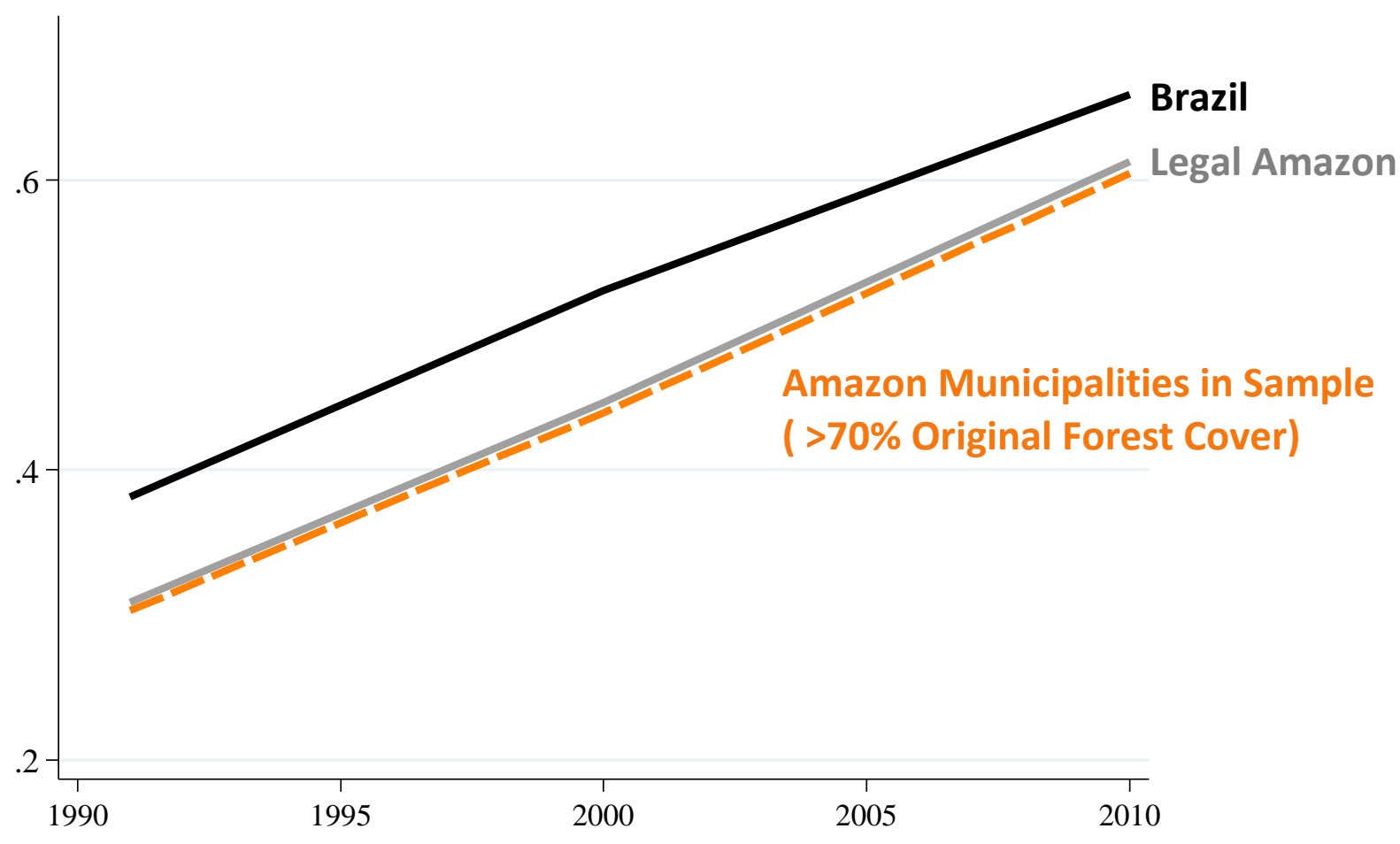

Figure 2: Human Development Index (HDI) by Population Type, 1991-2010 


\section{A. Change in HDI 1991-2010}

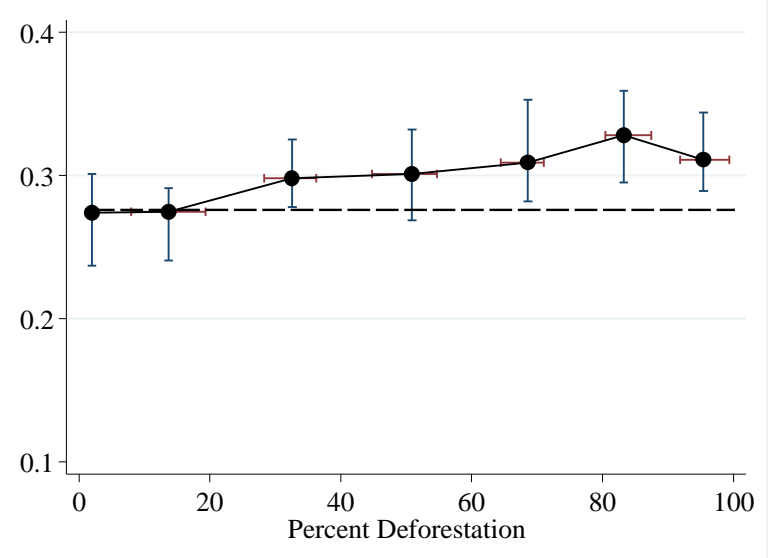

B. Change in HDI 1991-2000

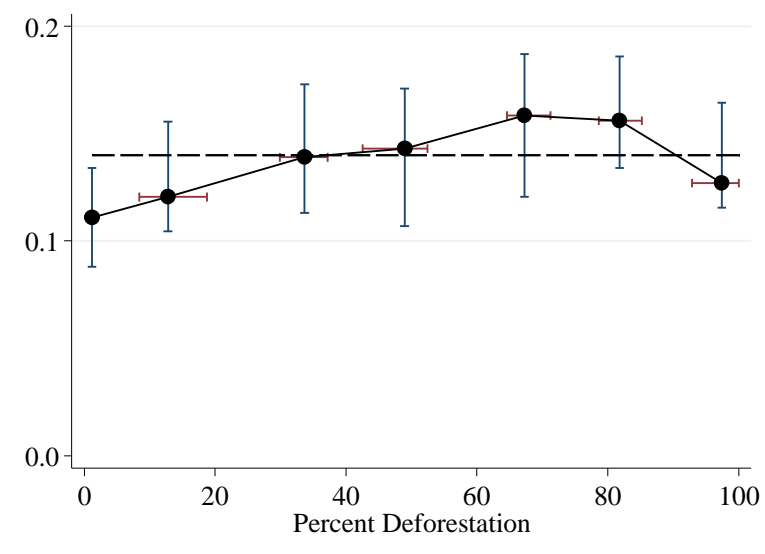

C. Change in HDI 2000-2010

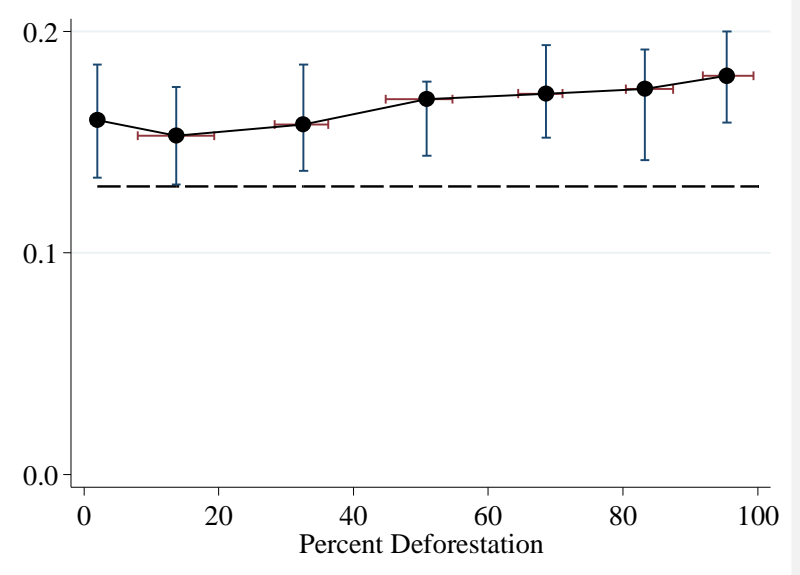

Figure 3. Testing the Boom-Bust Hypothesis. Circles represent median values; bars indicate first and third quartiles; horizontal dashed line represents the median across all Brazilian municipalities. 
A. Change in HDI 1991-2010

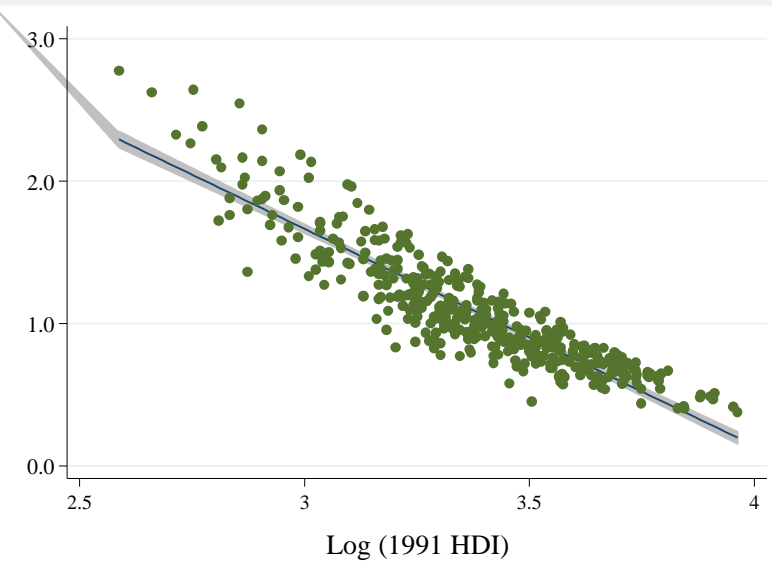

D. Change in Income Index 1991-2010

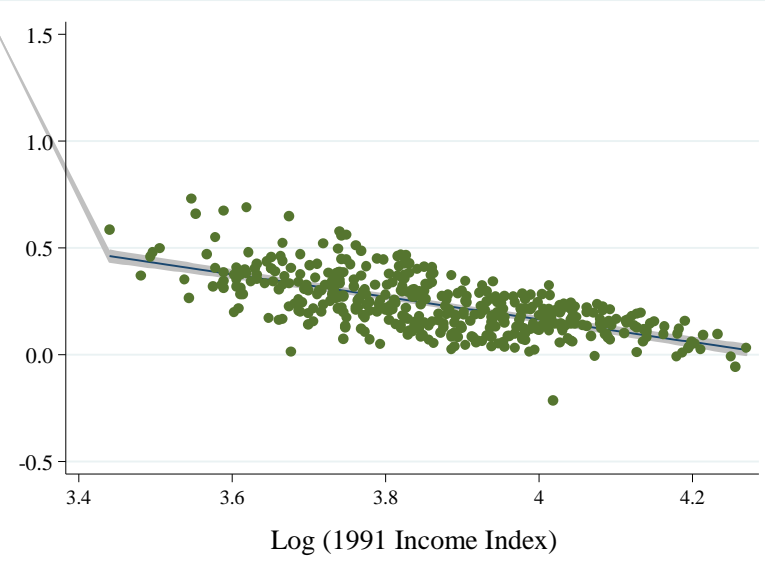

B. Change in HDI 1991-2000

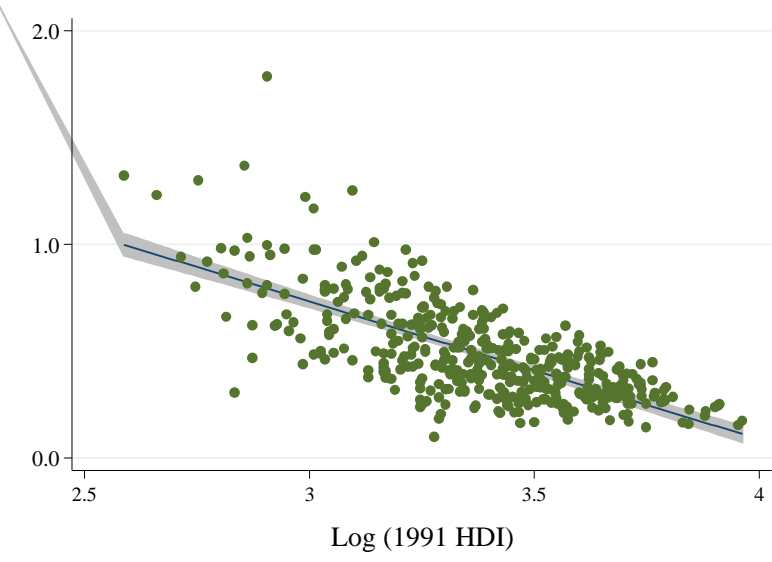

E. Change in Income Index 1991-2000

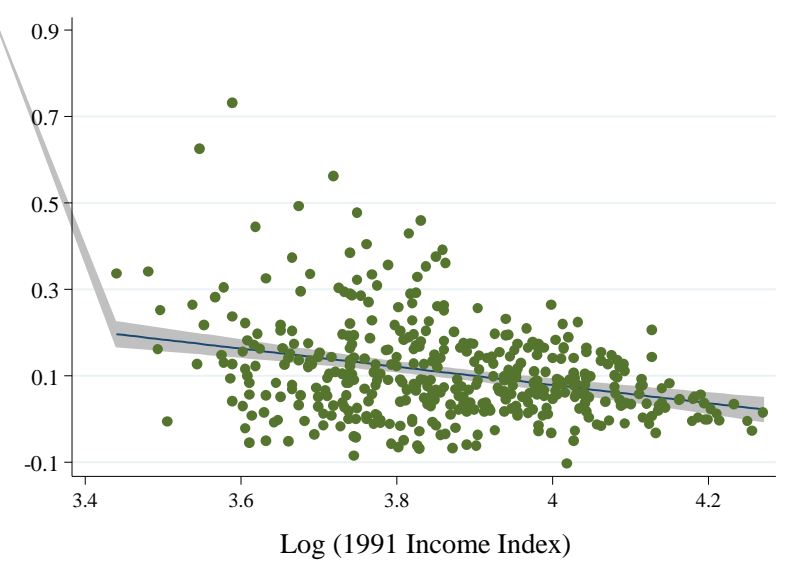

C. Change in HDI 2000-2010

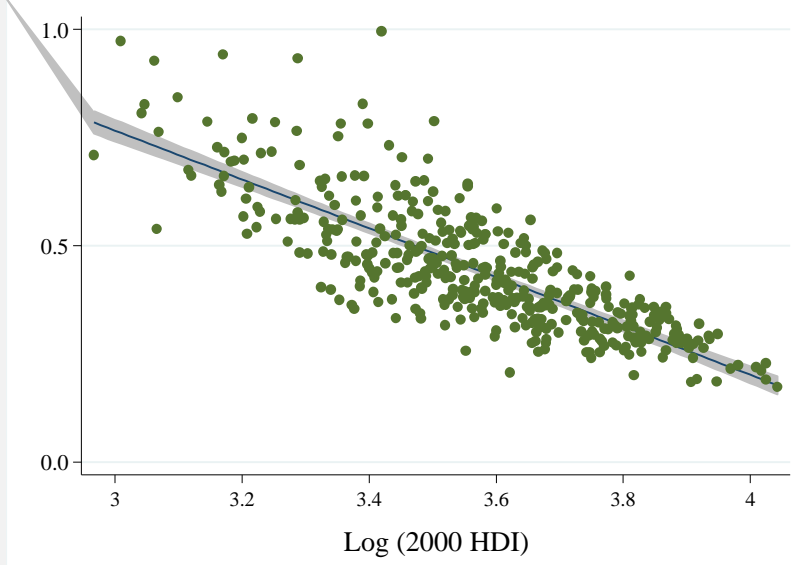

F. Change in Income Index 2000-2010

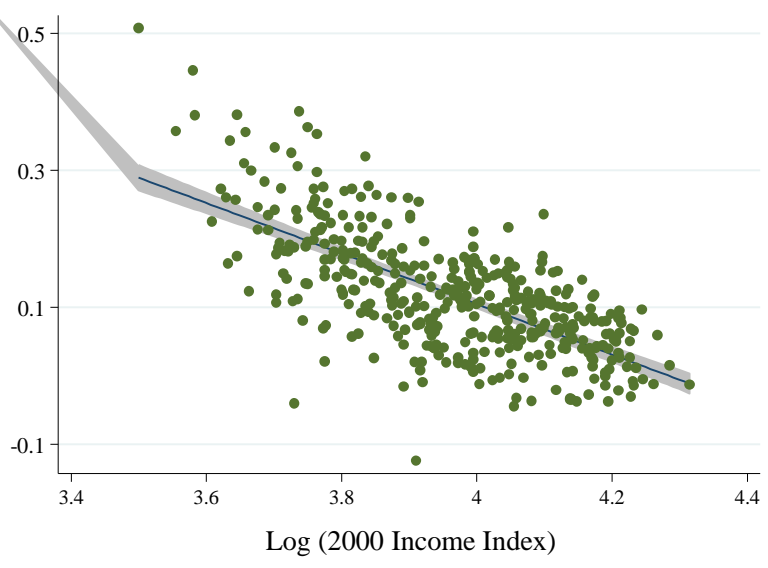

Figure 4. Testing Convergence within the Amazon. 95\% confidence interval shaded in gray $(n=423)$. In (A) R-squared=0.83 (B) Rsquared=0.50; (C) R-squared=0.64; (D) R-squared=0.43 (E) R-squared=0.10; $(F)$ R-squared=0.47; 95\% confidence interval shaded in gray. 


\section{A. Change in HDI 1991-2010}

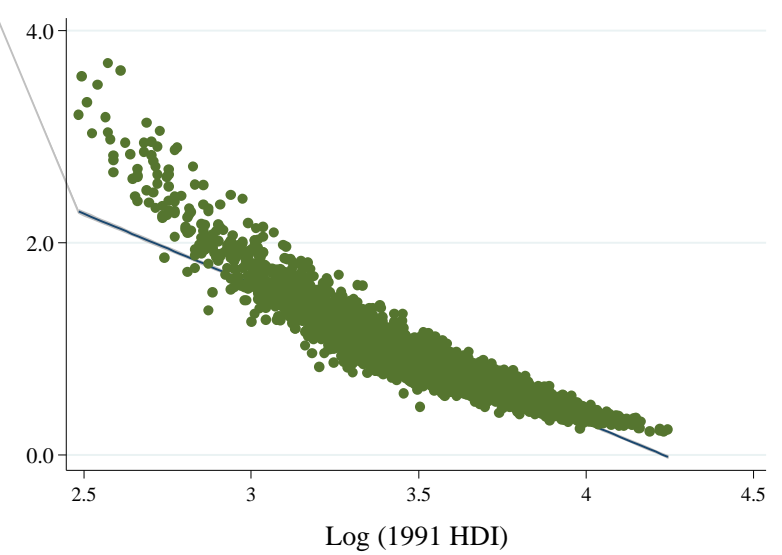

D. Change in Income Index 1991-2010

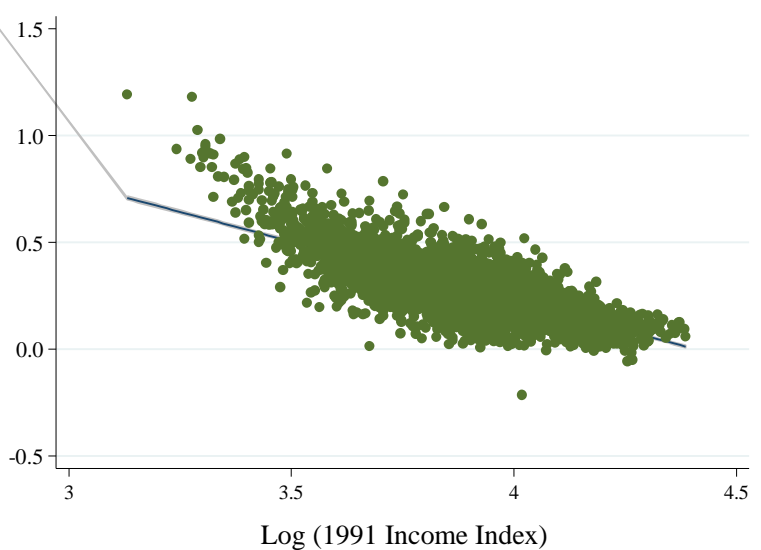

B. Change in HDI 1991-2000

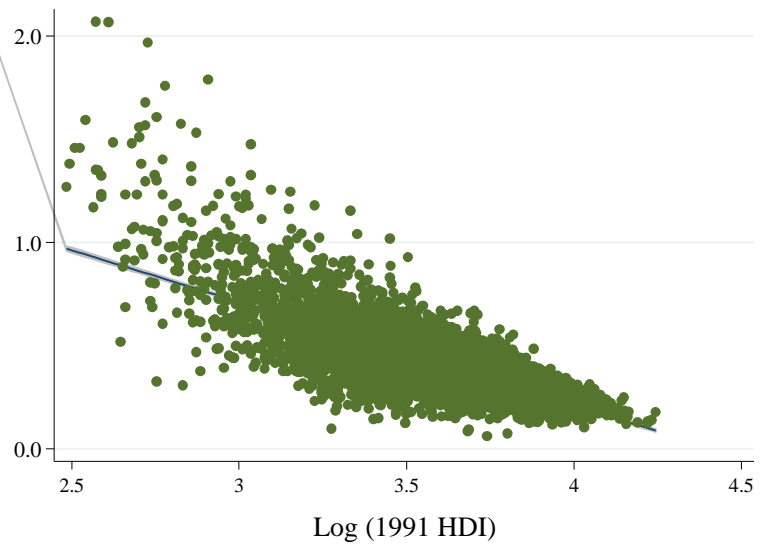

E. Change in Income Index 1991-2000

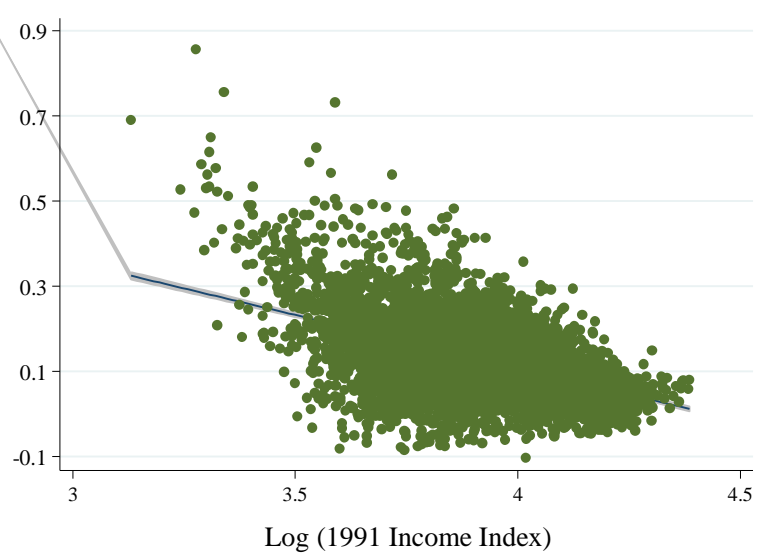

C. Change in HDI 2000-2010

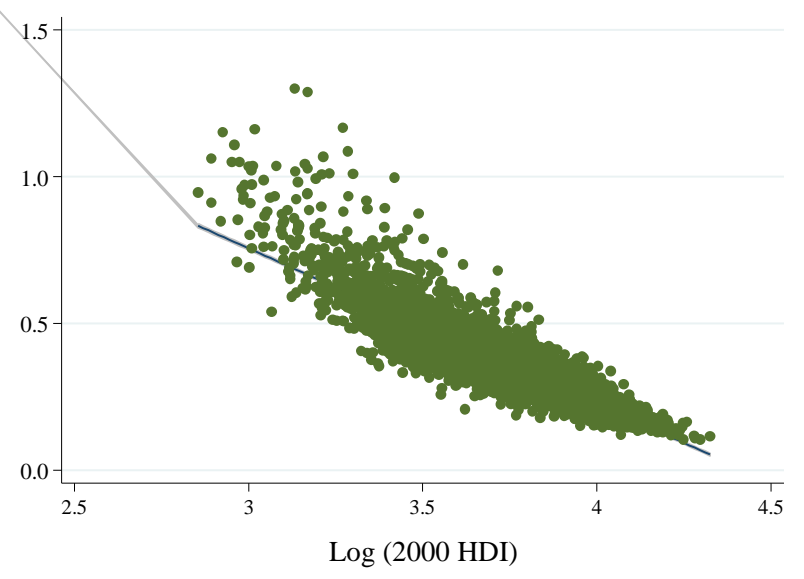

F. Change in Income Index 2000-2010

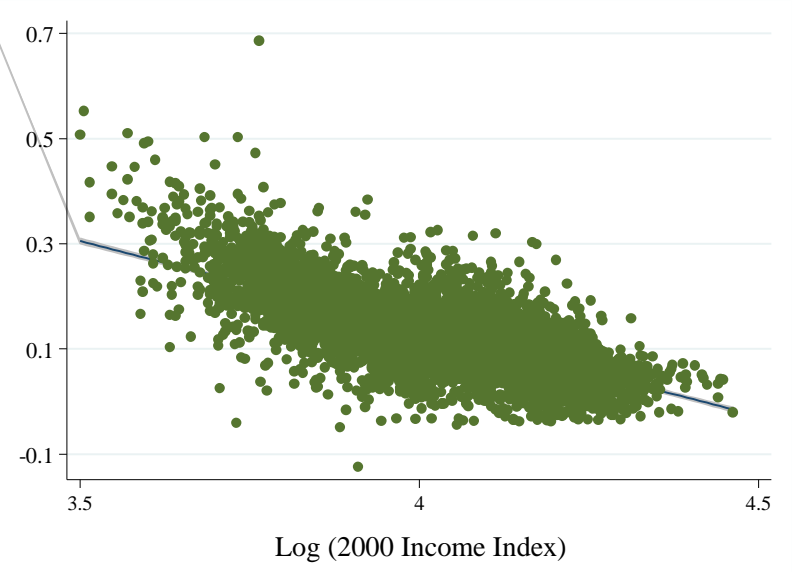

Figure 5. Testing Convergence within Brazil. 95\% confidence interval shaded in gray ( $n=5565)$. In (A) R-squared=0.89 (B) Rsquared=0.59; (C) R-squared=0.82; (D) R-squared=0.64; (E) R-squared $=0.27$; (F) R-squared $=0.51 ; 95 \%$ confidence interval shaded in gray. 


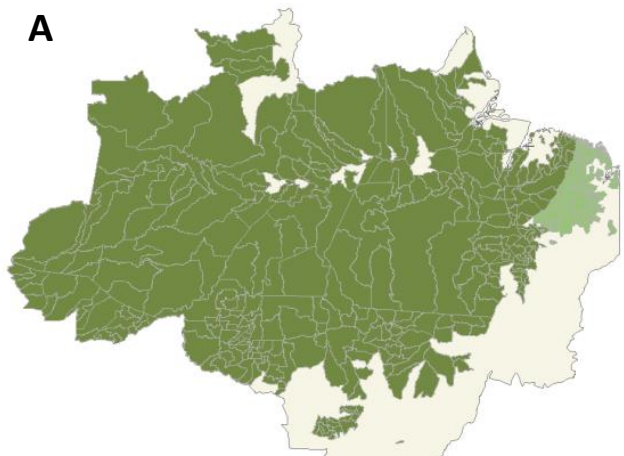

1991

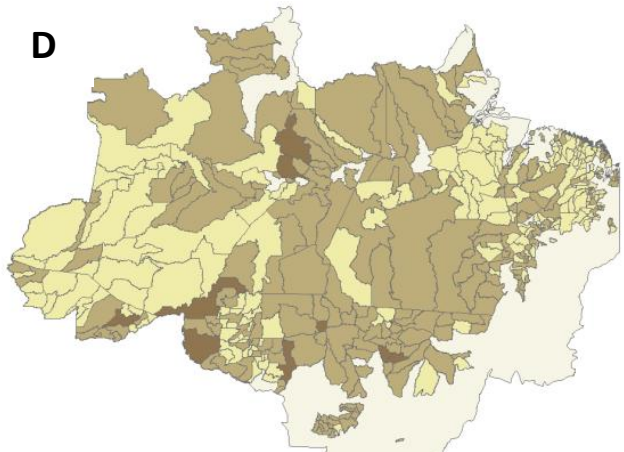

1991

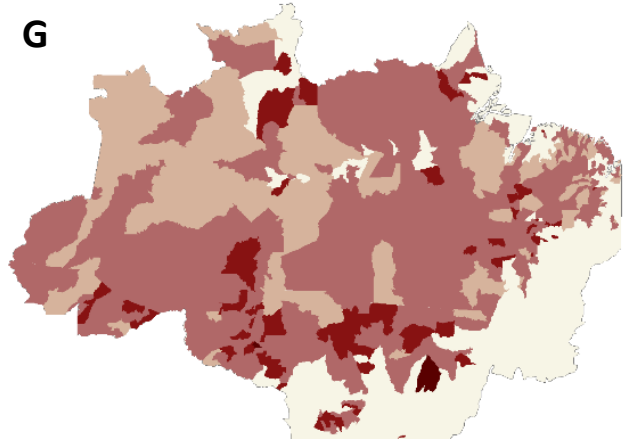

1991-2000

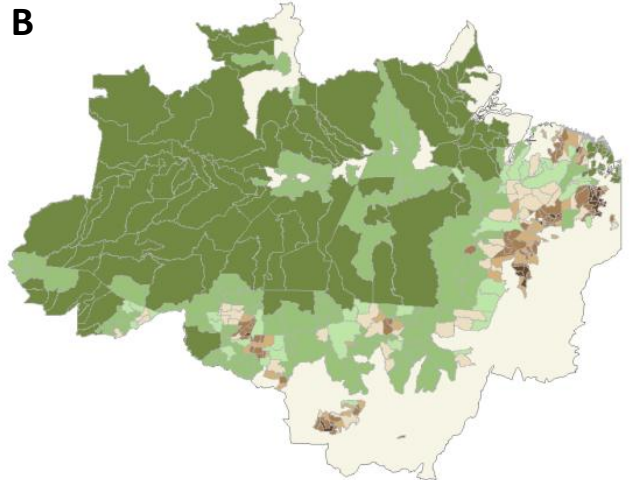

2000

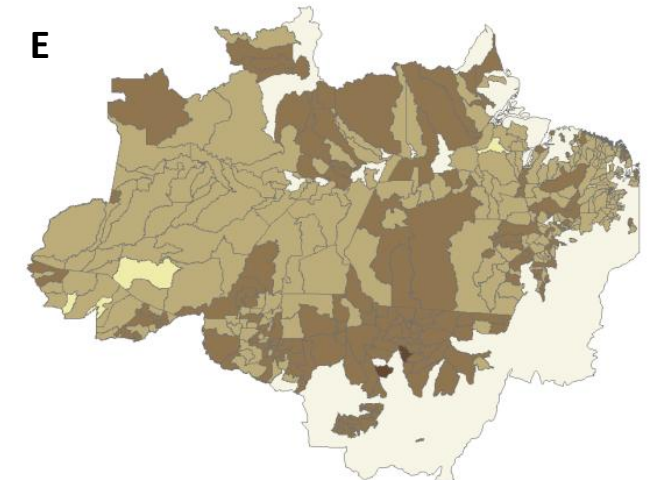

2000

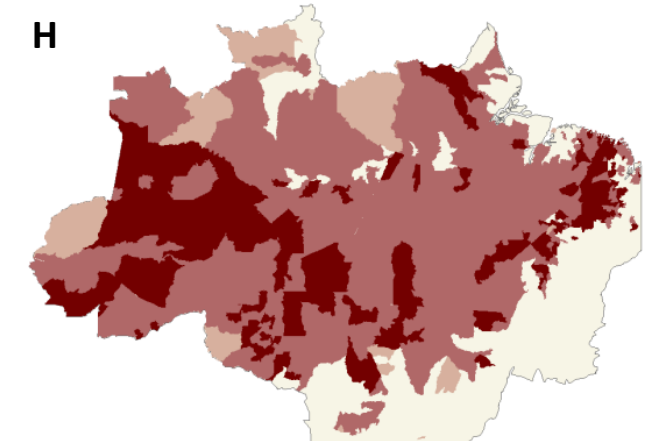

2000-2010

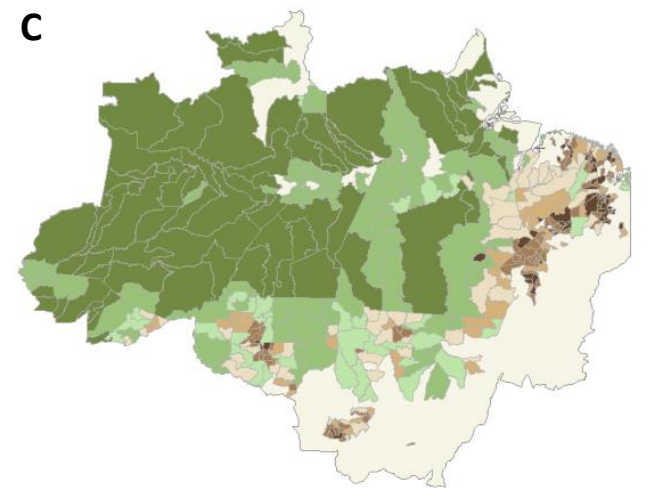

Land Area Deforested (\%)

$0 \%-5 \%$

$5.1 \%-25 \%$ $25.1 \%-40 \%$ $40.1 \%-60 \%$ $60.1 \%-75 \%$ $75.1 \%-90 \%$ $90.1 \%-100 \%$

2010

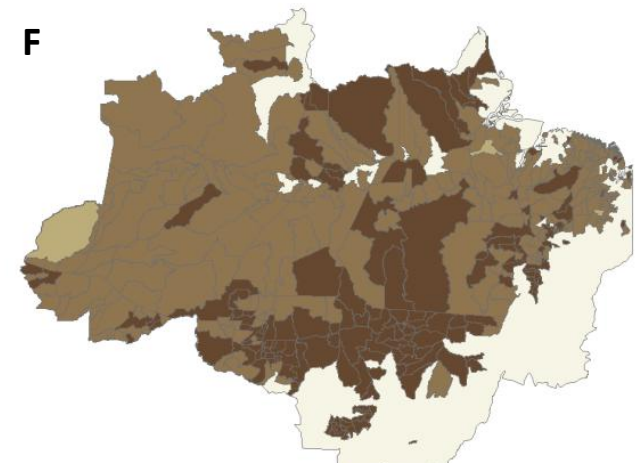

HDI

$0.123-0.289$ $0.290-0.456$ $0.457-0.622$ $0.623-0.788$

2010

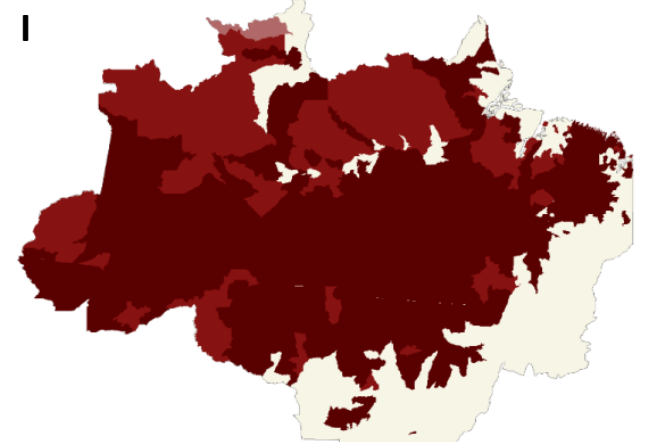

HDI Change

$0.03-0.10$ $0.11-0.18$ $0.19-0.25$ $0.26-0.33$

Figure 6. Map evidence of Amazonian municipality convergence for the years 1991, 2000, and 2010. 

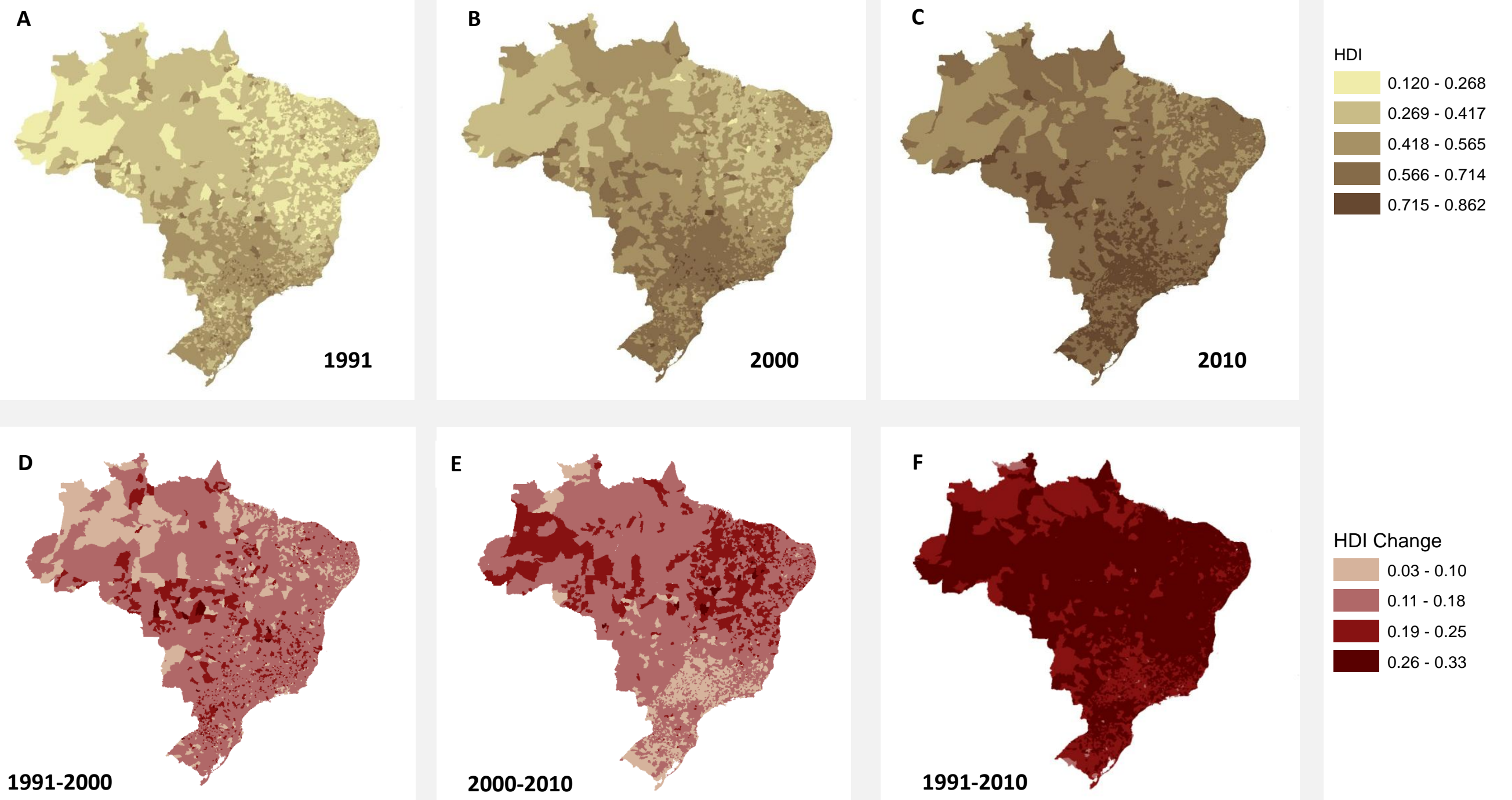

Figure 7. Map evidence of national municipality convergence for the years 1991, 2000, and 2010. 